Universidade de São Paulo

Escola Superior de Agricultura "Luiz de Queiroz"

Efeito do silício na utilização do fósforo pelas plantas de arroz

\title{
Rafhael Mendes Fehr
}

Dissertação apresentada para obtenção do título de Mestre em Ciências. Área de concentração: Solos e Nutrição de Plantas 


\section{Rafhael Mendes Fehr}

Engenheiro Agrônomo

Efeito do silício na utilização do fósforo pelas plantas de arroz

versão revisada de acordo com a resolução CoPGr 6018 de 2011

Orientador:

Prof. Dr. TAKASHI MURAOKA

Dissertação apresentada para obtenção do título de Mestre em Ciências. Área de concentração: Solos e Nutrição de Plantas

Piracicaba 


\section{Dados Internacionais de Catalogação na Publicação}

DIVISÃO DE BIBLIOTECA - DIBD/ESALQ/USP

Fehr, Rafhael Mendes

Efeito do silício na utilização do fósforo pelas plantas de arroz / Rafhael

Mendes Fehr. - - versão revisada de acordo com a resolução CoPGr 6018 de 2011. - -

Piracicaba, 2014.

$68 \mathrm{p}$ : il.

Dissertação (Mestrado) - - Escola Superior de Agricultura “Luiz de Queiroz”, 2014.

1. Diluição isotópica 2. Superfosfato triplo- ${ }^{32} \mathrm{P} 3$. Fontes silicatadas 4 . Wollastonita 5. Filossilicato 6. Aproveitamento do fertilizante I. Título

CDD 633.18

F296e

"Permitida a cópia total ou parcial deste documento, desde que citada a fonte - $\mathrm{O}$ autor" 


\section{DEDICO E OFEREÇO}

Aos meus pais, Thais Mendes e Celso Fehr e à minha irmã, Bruna Mendes Fehr, por todo o incentivo, confiança, amor e compreensão em todas as etapas de minha vida.

A Nathália Felipe Ansante, a quem confio e compartilho todos os meus objetivos e que, apesar das dificuldades encontradas durante o percurso, sempre caminhamos lado a lado.

A meu amigo e irmão Thiago Felipe Ansante, pelo companheirismo e pela amizade sincera. 


\section{AGRADECIMENTOS}

A Deus, fonte de inspiração, iluminação e proteção em todos os momentos de minha vida.

À Escola Superior de Agricultura "Luiz de Queiroz”, ESALQ/USP, pela oportunidade da realização do curso possibilitando meu crescimento pessoal e profissional.

Ao Centro de Energia Nuclear na Agricultura, CENA/USP, pela oportunidade de desenvolver meu projeto em suas dependências.

Ao Prof. Dr. Takashi Muraoka, pela oportunidade concedida, pela valiosa orientação, ensinamentos, incentivos, pela amizade e pelo exemplo de comportamento ético e profissional.

À Coordenação de Aperfeiçoamento de Pessoal de Nível Superior (CAPES), pela concessão da bolsa de estudos.

Ao corpo docente e administrativo do Departamento de Solos e Nutrição de Plantas da ESALQ/USP.

Ao Instituto Agronômico de Campinas (IAC) pelo apoio na obtenção das sementes de arroz utilizadas neste trabalho.

Ao Prof. Dr. Leandro José Grava de Godoy, da Universidade Estadual Paulista "Júlio de Mesquita Filho" (UNESP), Campus de Registro, pela amizade e pelas orientações e ensinamentos durante toda minha graduação e pelo apoio na realização do primeiro contato de estágio junto ao Prof. Dr. Takashi Muraoka.

Aos meus pais Thais Mendes e Celso Fehr e à minha irmã Bruna Mendes Fehr, pelo apoio e motivação em todas as etapas de minha formação profissional, pelo carinho e atenção dedicados nos momentos de dificuldades e pela compreensão devido à ausência.

A minha namorada, Nathália Felipe Ansante, Engenheira Agrônoma, pelo carinho, companheirismo, compreensão, amor e pela presença em todas as etapas deste processo.

Ao meu amigo e irmão, Thiago Felipe Ansante, pela amizade desde a graduação e apoio durante esta etapa.

A Sueli Conceição Mendes Felipe, Roque Miguel Ansante e Raphaela Felipe Ansante, por todo o incentivo e apoio nos momentos de dificuldade, durante todo este processo.

Aos colegas da sala de Pós Graduandos do Laboratório Fertilidade do Solo CENA/USP: Alinne Silva, Camila Leite, Cristiano Dela Piccolla, Fábio Ricardo, Fernando Guerra, Luiz Francisco Filho, Nericlenes Marcante, pelo auxílio e ótima convivência durante 
todo este período. Agradeço também a todos os colegas e amigos do Programa de Pósgraduação em Solos e Nutrição de Plantas da ESALQ/USP.

Aos técnicos e funcionários do Laboratório de Fertilidade do Solo - CENA/USP: Marileusa, Sandra e João por todo auxílio na parte das análises.

Ao Anderson Trevizam, pelo auxílio nas análises de silício.

A todos que de alguma forma, diretamente ou indiretamente, colaboraram para realização deste trabalho. 


\section{SUMÁRIO}

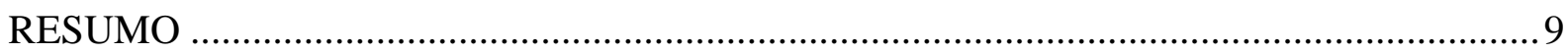

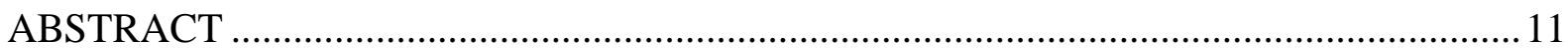

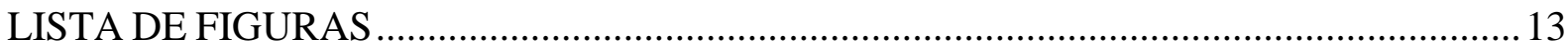

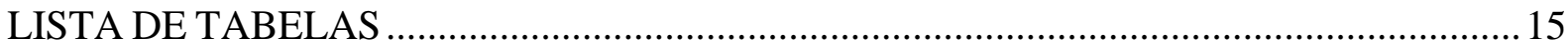

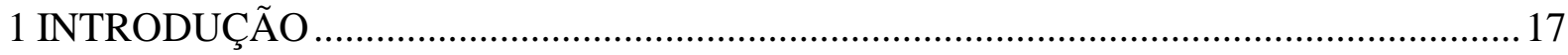

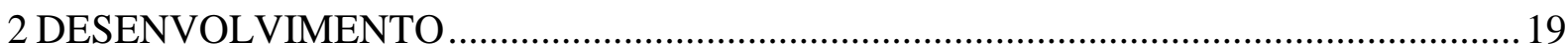

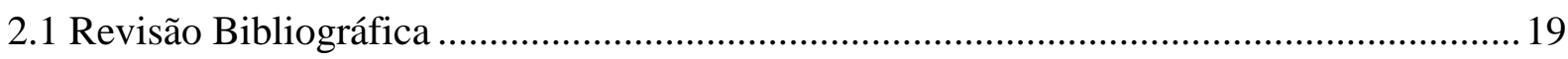

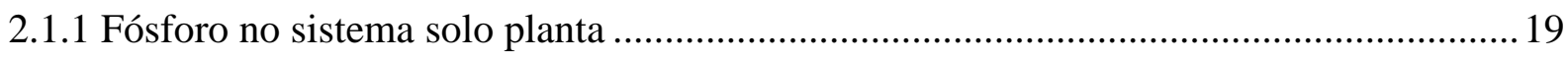

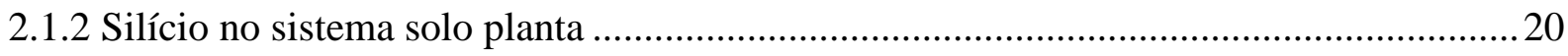

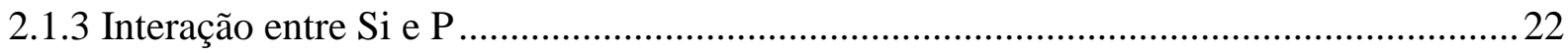

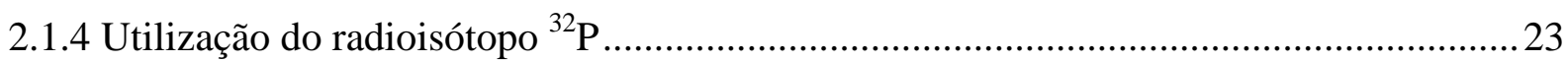

2.2.1 Caracterização do solo utilizado nos experimentos.........................................................24

2.2.2 Caracterização da fonte de fósforo …………………………………………………....2

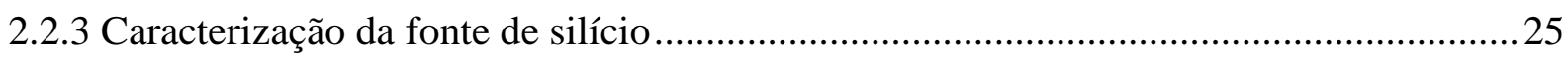

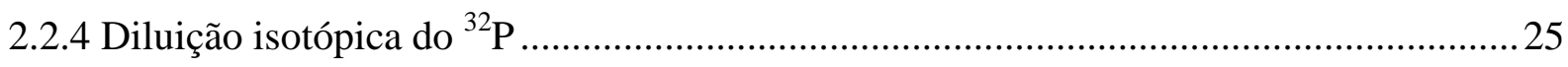

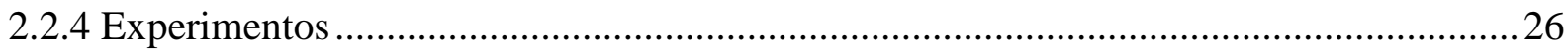

2.2.4.1 Experimento 1: Efeito das doses de silício no aproveitamento do fósforo do superfosfato triplo pelo arroz ................................................................................ 26

2.2.4.2 Experimento 2: Formas de aplicação de silício e fósforo no aproveitamento do P do

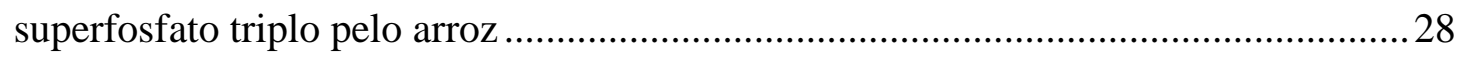

2.2.4.3 Experimento 3: Incubação do solo após a aplicação de fósforo e doses de silício........30

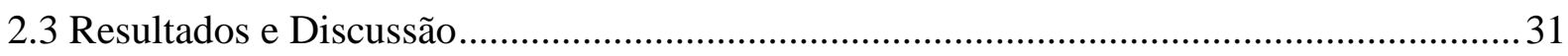

2.3.1 Experimento 1: Efeito das doses de silício no aproveitamento do fósforo do superfosfato

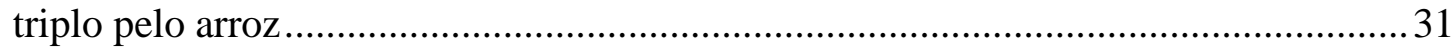

2.3.2 Experimento 2: Formas de aplicação de silício e fósforo no aproveitamento do

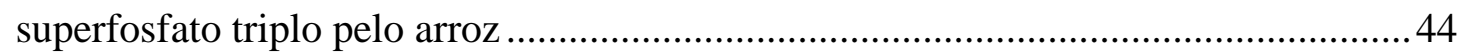

2.3.3 Experimento 3: Incubação do solo após a aplicação de fósforo e doses de silício...........49

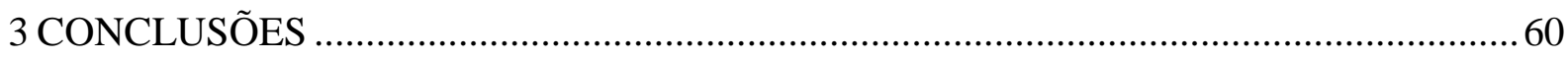

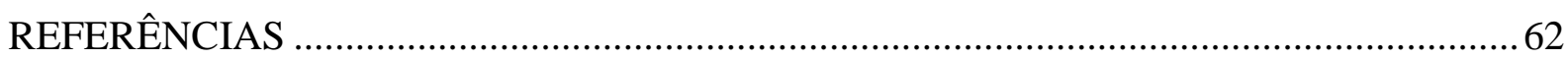




\section{RESUMO}

\section{Efeito do silício na utilização do fósforo pelas plantas de arroz}

Com o objetivo de avaliar os efeitos da interação entre o silício ( $\mathrm{Si}$ ) e o fósforo $(\mathrm{P})$ na planta e no solo, foram realizados três experimentos. No primeiro experimento, avaliou-se o efeito de duas fontes de $\mathrm{Si}$ (wollastonita e filossilicato) em diferentes doses ( 0 a $250 \mathrm{mg} \mathrm{dm}^{-3}$ ) sobre o aproveitamento do $\mathrm{P}$ do superfosfato triplo marcado com o radioisótopo ${ }^{32} \mathrm{P}$. Utilizouse o arroz (Oryza sativa) como planta teste. Neste primeiro experimento, as duas fontes de $\mathrm{Si}$ promoveram incremento na quantidade do elemento nas plantas, porém tiveram comportamento diferente quanto à produção de matéria seca da parte aérea e de $\mathrm{P}$ acumulado, tendo apenas o filossilicato promovido ganhos para estas variáveis. Constatou-se que o maior acúmulo do $\mathrm{P}$ pela planta em relação ao tratamento controle (sem $\mathrm{Si}$ ) foi devido à maior absorção do nutriente do solo e não do fertilizante, sendo baixo o aproveitamento do superfosfato triplo pelas plantas para as duas fontes de Si. No entanto, a wollastonita liberou maiores quantidades de Si no solo em relação ao filossilicato. No segundo experimento foram avaliadas as formas de aplicação (em sulco ou misturado ao solo) de Si e P no aproveitamento do $\mathrm{P}$ do superfosfato triplo pelo arroz. Aplicou-se uma dose de $\mathrm{Si}\left(125 \mathrm{mg} \mathrm{dm}^{-3}\right)$ intermediária daquelas utilizadas no primeiro experimento para ambas as fontes de $\mathrm{Si}$, wollastonita e filossilicato, e a mesma dose de $\mathrm{P}\left(53 \mathrm{mg} \mathrm{dm}^{-3}\right)$. De acordo com os resultados desse experimento, as duas fontes de $\mathrm{Si}$ apresentaram respostas similares, não havendo diferença para nenhuma variável analisada. No terceiro experimento foi realizado um teste de incubação (sem planta), no qual se aplicou as mesmas doses de Si do primeiro experimento ( 0 a $250 \mathrm{mg}$ $\left.\mathrm{dm}^{-3}\right)$ e a mesma dose de $\mathrm{P}\left(53 \mathrm{mg} \mathrm{dm}^{-3}\right)$, a fim de avaliar o comportamento da liberação de Si pelas fontes wollastonita e filossilicato em função do tempo, entre 0 a 90 dias. Foram realizadas coletas mensais de amostras do solo. Verificou-se que ambas as fontes de $\mathrm{Si}$ apresentaram a maior liberação deste elemento no solo próximo aos 60 dias após a aplicação. $\mathrm{O}$ teor de $\mathrm{P}$ no solo, no terceiro experimento (de incubação do solo), apesar de ter sido aplicado em uma única dose, comportou-se de maneira similar ao $\mathrm{Si}$, tendo aumentado com o passar do tempo e obtendo valor máximo próximo de dois meses após a aplicação. Nos três experimentos, verificou-se que apesar do extrator ácido acético indicar maior teor de Si no solo, o extrator cloreto de cálcio obteve dados mais coerentes quando comparado com o $\mathrm{Si}$ acumulado na parte aérea das plantas de arroz. Dessa forma, a utilização do Si pode constituir um componente útil para o manejo da adubação, tendo em vista que houve interação positiva com o P, que é um dos nutrientes mais limitantes nos solos brasileiros.

Palavras-chave: Diluição isotópica; Superfosfato triplo- ${ }^{32} \mathrm{P}$; Fontes silicatadas; Wollastonita; Filossilicato; Aproveitamento do fertilizante 


\section{ABSTRACT \\ Effect of silicon on phosphorus utilization by rice plants}

With the aim of evaluating the effects of the interaction between the silicon $(\mathrm{Si})$ and phosphorus (P) in plant and soil, three experiments were carried. In the first experiment, the effect of two sources of $\mathrm{Si}$ (wollastonite and phyllosilicate) at different doses $(0-250 \mathrm{mg} \mathrm{dm}$ 3 ) on P recovery from triple superphosphate labeled with the radioisotope $32 \mathrm{P}$ was evaluated. We used the rice (Oryza sativa) as a test plant. In this first experiment, the two sources of Si promoted increase in the amount of the element in plants, but have different behavior regarding the production of dry matter of shoots and $\mathrm{P}$ uptake, with only the phyllosilicate promoted gains for these variables. It was found that the greater accumulation of $\mathrm{P}$ by the plant compared to the control treatment (without $\mathrm{Si}$ ) was due to higher absorption of nutrients from the soil and fertilizer, and low utilization of the triple superphosphate by plants to the two sources of Si However, wollastonite released higher amounts of Si in the soil in relation to the phyllosilicate. In the second experiment the application forms (in groove or mixed with soil) of Si and P in P recovery from triple superphosphate for rice were evaluated. Applied a dose of $\mathrm{Si}$ (125 mg dm-3) intermediate from those used in the first experiment for both sources of $\mathrm{Si}$, wollastonite and phyllosilicate, and the same dose of $\mathrm{P}(53 \mathrm{mg} \mathrm{dm}-3)$. According to the results of this experiment, the two sources of Si showed similar responses, with no differences for any variable analyzed. In the third experiment a test incubation (no plant) in which applied the same doses of $\mathrm{Si}$ in the first experiment (0 to $250 \mathrm{mg} \mathrm{dm}-3$ ) and the same dose of $\mathrm{P}$ (53 mg dm-3) was performed to order to evaluate the behavior of the wollastonite for Si sources and phyllosilicate a function of time, between 0-90 days. Monthly collections of soil samples were taken. It was found that both sources of Si had the highest soil release in the next 60 days after application. The content of $\mathrm{P}$ in the third experiment (incubation ground), although it has been applied in a single dose, behaved similarly, and increased with the passage of time and getting maximum near two months the application. In three experiments, we found that despite the extractor acetic acid indicate higher Si content in the soil, the extractor calcium chloride obtained more consistent data when compared with the $\mathrm{Si}$ accumulated in shoots of rice plants. Thus, the use of Si can be a useful for fertilization management component, considering that there was a positive interaction with $\mathrm{P}$, which is one of the most limiting nutrients in Brazilian soils.

Keywords: Isotopic dilution; Superphosphate- ${ }^{32} \mathrm{P}$; Silicate sources; Wollastonite; Phyllosilicate; Fertilizer P utilization 


\section{LISTA DE FIGURAS}

Figura 1 - Efeito de fontes e doses de silício na produção de massa seca da parte aérea (MSPA) de arroz..... 31

Figura 2 - Efeito de fontes e doses de silício (Si) no fósforo (P) acumulado na massa seca da parte aérea de arroz. 33

Figura 3 - Efeito de fontes e doses de silício $(\mathrm{Si})$ no teor de fósforo $(\mathrm{P})$ no solo extraído pela resina trocadora de íons $\left(\mathrm{mg} \mathrm{dm}^{-3}\right)$.

Figura 4 - Efeito de fontes e doses de silício ( $\mathrm{Si}$ ) no Si acumulado na massa seca da parte aérea de arroz. 38

Figura 5 - Efeito de fontes e doses de silício ( $\mathrm{Si}$ ) no teor de Si no solo extraído pelo cloreto de cálcio.

Figura 6 - Efeito de fontes e doses de silício ( $\mathrm{Si}$ ) no teor de $\mathrm{Si}$ no solo extraído pelo ácido acético.

Figura 7 - Efeito de doses de wollastonita no teor de Si no solo extraído pelo cloreto de cálcio e ácido acético.

Figura 8 - Teor de silício (Si) no extraído por cloreto de cálcio $\left(\mathrm{CaCl}_{2}\right)$ em função da aplicação de doses de wollastonita.

Figura 9 - Teor de silício ( $\mathrm{Si}$ ) no solo extraído por cloreto de cálcio $\left(\mathrm{CaCl}_{2}\right)$ em função da aplicação de doses de filossilicato.

Figura 10 - Teor de silício (Si) no solo $\left(\mathrm{mg} \mathrm{dm}^{-3}\right)$ extraído por cloreto de cálcio pela aplicação de 200 e $250 \mathrm{mg} \mathrm{dm}^{-3}$ de Si via wollastonita em função dos dias de incubação.

Figura 11 - Teor de silício $(\mathrm{Si})$ no solo $\left(\mathrm{mg} \mathrm{dm}^{-3}\right)$ extraído por cloreto de cálcio pela aplicação de 200 e $250 \mathrm{mg} \mathrm{dm}^{-3}$ de Si via filossilicato em função dos dias de incubação. 53 Figura 12 - Teor de silício ( $\mathrm{Si}$ ) no solo extraído por ácido acético, em função da aplicação de fontes e doses de $\mathrm{Si}$.

Figura 13 - Teor de silício ( $\mathrm{Si})$ no solo $\left(\mathrm{mg} \mathrm{dm}^{-3}\right)$ extraído por ácido acético pela aplicação de $50,100,150,200$ e $250 \mathrm{mg} \mathrm{dm}^{-3}$ de Si via wollastonita em função dos dias de incubação. ....55 Figura 14 -Teor de silício ( $\mathrm{Si}$ ) no solo $\left(\mathrm{mg} \mathrm{dm}^{-3}\right)$ extraído por ácido acético pela aplicação de 50, 100, 150 e $200 \mathrm{mg} \mathrm{dm}^{-3}$ de Si via filossilicato em função dos dias de incubação. 56

Figura 15 - Teor de fósforo (P) no solo $\left(\mathrm{mg} \mathrm{dm}^{-3}\right)$ pela aplicação fontes wollastonita e fillossilicato nas doses de Si 0, 50, 150, 200 e $250 \mathrm{mg} \mathrm{dm}^{-3}$ incubadas no solo. .57 
Figura 16 - Teor de fósforo (P) no solo $\left(\mathrm{mg} \mathrm{dm}^{-3}\right)$ pela aplicação de 50; 100; 150 e $200 \mathrm{mg}$ $\mathrm{dm}^{-3}$ de Si via wollastonita em função dos dias de incubação. ............................................... 58 Figura 17 - Teor de fósforo (P) no solo ( $\mathrm{mg} \mathrm{dm}^{-3}$ ) pela aplicação de 50; 100; 150 e $200 \mathrm{mg}$ $\mathrm{dm}^{-3}$ de Si via filossilicato em função dos dias de incubação.................................................. 59 


\section{LISTA DE TABELAS}

Tabela 1 - Caracterização das propriedades químicas do solo utilizado nos experimentos.....25

Tabela 2 - Tratamentos de fontes de silício ( $\mathrm{Si}$ ) e doses aplicadas no solo.............................27

Tabela 3 - Tratamentos de fontes de silício ( $\mathrm{Si}$ ) e formas de aplicação no solo. .....................29

Tabela 4 - Tratamentos de doses e fontes de silício (Si) aplicados para incubação do solo. ... 30

Tabela 5 - Produção de massa seca da parte aérea (MSPA) $\left(\mathrm{g} \mathrm{vaso}^{-1}\right)$ em função de fontes de

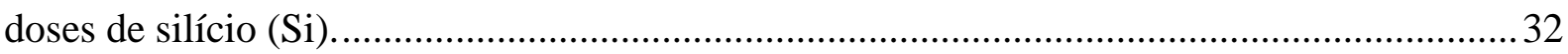

Tabela 6 - Fósforo (P) acumulado na parte aérea do arroz em função de fontes de doses de

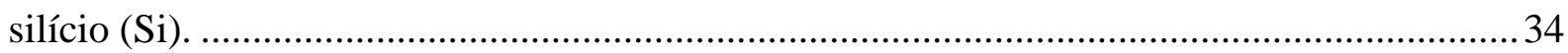

Tabela 7 - Teor de fósforo (P) no solo extraído pela resina trocado de íons $\left(\mathrm{mg} \mathrm{dm}^{-3}\right)$ em

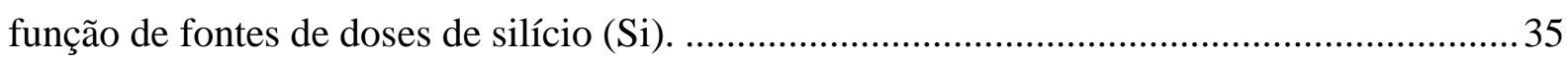

Tabela 8 - Teor de fósforo (P) na planta proveniente do fertilizante (Pppf) (mg vaso $\left.{ }^{-1}\right)$ em funcao de fontes e doses de $\mathrm{Si}$.......

Tabela 9 - Aproveitamento do fósforo (AP) (\%) via superfosfato triplo (SFT) em função de

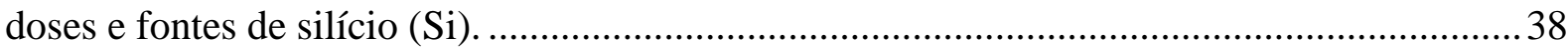

Tabela 10 - Teor de silício ( $\mathrm{Si}$ ) acumulado na massa seca da parte aérea (MSPA) do arroz $\left(\mathrm{mg} \mathrm{vaso}^{-1}\right)$ em função de fontes de doses de Si.

Tabela 11 - Teor de silício ( $\mathrm{Si})$ no solo pelo extrator cloreto de cálcio $\left(\mathrm{CaCl}_{2}\right)$ em função de fontes e doses de $\mathrm{Si}$

Tabela 12 - Teor de silício ( $\mathrm{Si}$ ) no solo extraído pelo ácido acético em função de fontes e doses de $\mathrm{Si}$.

Tabela 13 - Massa seca de parte área (MSPA) do arroz $\left(\mathrm{g} \mathrm{vaso}^{-1}\right)$ em função das formas de aplicação do silício (Si), em área total e localizada, para as fontes wollastonita e filossilicato.

Tabela 14 - Fósforo (P) acumulado na planta (mg vaso ${ }^{-1}$ ) em arroz em função da forma de aplicação, área total e localizada, para as fontes de silício ( $\mathrm{Si}$ ) wollastonita e filossilicato..... 45 Tabela 15 - Fósforo $(\mathrm{P})$ no solo $\left(\mathrm{mg} \mathrm{dm}^{-3}\right)$ em função das formas de aplicação, área total e localizada, das fontes wollastonita e filossilicato.

Tabela 16 - Teor de fósforo na planta proveniente do fertilizante (Pppf) (mg vaso ${ }^{-1}$ ) em função de formas de aplicação, área total e localizada, das fontes wollastonita e filossilicato......

Tabela 17 - Aproveitamento do fósforo (AP) do superfosfato triplo em função de formas de aplicação, área total e localizada, das fontes wollastonita e filossilicato. 
Tabela 18 - Silicio (Si) acumulado $\left(\mathrm{mg} \mathrm{vaso}^{-1}\right)$ em plantas de arroz em função da forma de aplicação, área total e localizada, das fontes de silício ( $\mathrm{Si}$ ) wollastonita e filossilicato. 48 Tabela 19 - Teor de silício ( $\mathrm{Si})\left(\mathrm{mg} \mathrm{dm}^{-3}\right)$ extraído pelo cloreto de cálcio $\left(\mathrm{CaCl}_{2}\right)$ em função das formas de aplicação, área total e localizada, das fontes wollastonita e filossilicato. 49 Tabela 20 - Teor de silício ( $\mathrm{Si})\left(\mathrm{mg} \mathrm{dm}^{-3}\right)$ extraído pelo ácido acético em função das formas de aplicação, área total e localizada, das fontes wollastonita e filossilicato. 49 Tabela 21 - Teor de silício ( $\mathrm{Si})$ no solo $\left(\mathrm{mg} \mathrm{dm}^{-3}\right)$ extraído pelo cloreto de cálcio $\left(\mathrm{CaCl}_{2}\right)$ para doses das fontes de Si wollastonita e filossilicato...... 51 Tabela 22 - Teor de silício (Si) no solo pelo extrator ácido acético em função de doses e fontes de $\mathrm{Si}$, wollastonita e filossilicato. 54 Tabela 23 - Teor de fósforo (P) no solo $\left(\mathrm{mg} \mathrm{dm}^{-3}\right)$ em função das doses das fontes de silício (Si), wollostonita e filossicato, no tempo 0 de incubação. 59 


\section{INTRODUÇÃO}

$\mathrm{O}$ arroz (Oryza sativa), de acordo com a Food and Agriculture Organization (FAO, 2010), é a principal fonte de alimento para mais da metade da população mundial. O Brasil é considerado o maior produtor deste cereal cultivado em sequeiro e nono maior produtor do mundo, analisando os dois sistemas de cultivo (sequeiro e irrigado). A safra brasileira de arroz em 2013/14 está estimada em 12,2 milhões de toneladas, superando em 3 \% a safra anterior. Este incremento na produção, de acordo com a Companhia Nacional de Abastecimento (CONAB), ocorreu principalmente em virtude das boas condições de plantio, expansão da área plantada no Centro-Oeste do país, que passou de 225 para 244 mil ha nesta safra em face do elevado patamar de preços do produto (CONAB, 2014). A área plantada com arroz de sequeiro fica concentrada na região Centro-Oeste (Mato Grosso e Goiás); Nordeste (Piauí e Maranhão) e Norte (Pará e Rondônia), sendo que esse sistema é responsável por 40\% da produção nacional (BRASIL, 2014).

De acordo com a Assessoria de Gestão Estratégica do Ministério da Agricultura, Pecuária e Abastecimento (MAPA) em 2014, as projeções de produção de arroz evidenciam que o Brasil irá colher 14,12 milhões de toneladas na safra 2019/2020. Todavia, o consumo deverá crescer a uma taxa média anual de $0,86 \%$, alcançando 14,37 milhões de toneladas em 2019/2020. Assim, a importação projetada para o final do período é de 252,85 mil toneladas, confirmando que poderá haver déficit deste alimento, pois a taxa anual projetada para o consumo nos próximos anos está ligeiramente abaixo da expectativa de consumo da população brasileira.

As pesquisas atuais priorizam ações para consolidar a presença da cultura e aumentar a produtividade, em sistemas de produção de grãos nas regiões no Cerrado (BRASIL, 2014). Entretanto estes solos possuem baixa fertilidade natural, consequentemente, seu potencial produtivo é limitado principalmente pela baixa disponibilidade do fósforo $(\mathrm{P})$, dado a grande capacidade dos solos, principalmente das regiões tropicais, em reter este nutriente em formas não disponíveis às plantas (NOVAIS et al., 2007, FERNANDEZ et al., 2008a, 2008b).

Tendo em vista a crescente demanda por alimento e o interesse pela intensificação produtiva da orizicultura de sequeiro em regiões com baixa disponibilidade de $\mathrm{P}$, faz-se necessário estudo com o objetivo de desenvolver estratégias para aumentar a eficiência das adubações, sobretudo fosfatadas. Sendo uma dessas possibilidades, com a utilização do silício $(\mathrm{Si})$. 
O Si é considerado micronutriente no Brasil, através do Decreto Lei 4.954/2004, porém é um dos elementos mais absorvidos pelas plantas de arroz (KORNDÖRFER; DATNOFF; CORRÊA 1999; TOKURA et al., 2011). Em solos que possuem alto grau de intemperismo, características comuns dos solos brasileiros, esse elemento pode estar em baixas concentrações e pouco disponível às plantas (BARBOSA FILHO et al., 2001; FAGERIA; BALIGAR; JONES, 2011).

Dependendo da concentração no solo, o Si pode competir com outros ânions, como o fosfato, pelos sítios de adsorção da fase sólida, podendo tornar o P mais disponível para as plantas (MA et al., 2001). Assim, a hipótese formulada é que a interação entre P e Si no solo pode resultar em aumento na disponibilidade do íon fosfato. Dessa forma, objetivou-se estudar a influência da adubação silicatada, sobre a eficiência da adubação fosfatada avaliada através do efeito na massa seca, absorção de P pela planta proveniente do fertilizante, assim como no teor de P e Si no solo e acúmulo na planta. 


\section{DESENVOLVIMENTO}

\subsection{Revisão Bibliográfica}

\subsubsection{Fósforo no sistema solo planta}

$\mathrm{O}$ teor de $\mathrm{P}$ nos solos é menor do que outros macronutrientes como o nitrogênio e potássio. A quantidade total de $\mathrm{P}$ na camada superficial dos solos varia entre 0,005 a $0,15 \%$ (HAVLIN et al., 2005). As plantas geralmente apresentam teores de P em torno de 0,1 e $0,5 \%$ em seus tecidos. As duas principais formas que o $\mathrm{P}$ é absorvido do solo pelas plantas são $\mathrm{H}_{2} \mathrm{PO}_{4}{ }^{-}$e $\mathrm{HPO}_{4}{ }^{-2}$, sendo dependente do $\mathrm{pH}$ do solo (TISDALE; BEATON; HAVLIN, 1993).

As funções do $\mathrm{P}$ nas plantas estão relacionadas com seu metabolismo, através da transferência de energia da célula, na respiração e na fotossíntese. É também componente estrutural dos ácidos nucléicos e cromossomos, assim como de muitas coenzimas, fosfoproteínas e fosfolipídeos (GRANT et al., 2001; EPSTEIN; BLOOM, 2006). O P também possui grande importância no processo de desenvolvimento das raízes. Assim, interfere diretamente no crescimento da planta, pois proporciona aumento da área de exploração do sistema radicular, melhorando a eficiência de absorção dos nutrientes e de água (BAHL; PARISCHA, 1998).

A maioria dos solos de regiões tropicais apresentam baixas quantidades de $\mathrm{P}$ na forma disponível para as culturas e, consequentemente, é o nutriente que mais limita a produção agrícola (NOVAIS; SMITH, 1999). Isso ocorre em função da natural escassez e pelas reações que ocorrem no solo através da fixação deste elemento aos óxidos de Fe e Al. Com o passar do tempo, a parte do P que fica adsorvido nos colóides sofre difusão para seu interior, sendo que, este processo pode demorar anos para atingir o equilíbrio, mas segundo Barrow (1985), este fenômeno é responsável pela diminuição do $\mathrm{P}$ disponível à planta, em um solo recémadubado.

A quantidade de $\mathrm{P}$ absorvido pelas plantas em relação à quantidade aplicada é baixa. $\mathrm{O}$ aproveitamento dos fertilizantes fosfatados pelas plantas, principalmente em solos tropicais, possui grandes limitações. A estimativa é de aproveitamento é próximo de $10 \%$ (BALIGAR; BENNETT, 1986).

Souza et al. (1999), em trabalho desenvolvido com gramíneas, mostraram que o baixo teor de $\mathrm{P}$ disponível às plantas é a principal limitação para o desenvolvimento das culturas nos solos brasileiros, fazendo com que haja necessidade de altas doses de fertilizantes fosfatados 
para suprir as necessidades das plantas. Isso ocorre principalmente em função de reações de adsorção aos óxidos e precipitação com ferro e alumínio, contribuindo com a imobilização do nutriente e consequentemente baixa mobilidade no solo. A Associação Nacional para Difusão de Adubos (ANDA) estima que, de modo geral, menos de $20 \%$ do $\mathrm{P}$ solúvel adicionado ao solo como adubo seja aproveitado pela cultura que o recebeu, sendo o restante fixado no solo. Neptune et al. (1979) já haviam constatado, usando superfosfato triplo marcado com ${ }^{32} \mathrm{P}$, que em feijoeiro o aproveitamento do P de fertilizante não atinge nem $10 \%$.

Segundo Grant (2001), em casos de déficit de P, pode ocorrer redução da respiração e da taxa fotossintética da planta, além de poder reduzir a síntese de proteínas e ácidos nucleicos. Em plantas de ciclo anual, a deficiência de P irá acarretar em um crescimento prejudicado e mais lento tanto da parte aérea quanto das raízes, deixando a planta com aspecto estiolado. A parte aérea ira apresentar coloração verde-escuro, com as nervuras em tonalidade arroxeada, principalmente na parte abaxial, além do sistema radicular reduzido (BINGHAM, 1966).

\subsubsection{Silício no sistema solo planta}

De acordo com a exigência de $\mathrm{Si}$, as plantas podem ser classificadas em três categorias: como acumuladoras, intermediárias e não acumuladoras de $\mathrm{Si}$, dependendo da quantidade deste elemento que estas absorvem (MA; TAKAHASHI, 2002; HODSON et al., 2005).

As plantas acumuladoras, de modo geral quase todas as gramíneas, como o arroz, recebem esta classificação quando contém $\mathrm{Si}$ acima de $4 \%$ na forma de $\mathrm{SiO}_{2}$ em seus tecidos vegetais. Plantas em que o teor de $\mathrm{SiO}_{2}$ varia entre 2 - $4 \%$, recebem a classificação de intermediárias.

Dentre as gramíneas, o arroz é a espécie que possui maior capacidade de absorção do $\mathrm{Si}$, devido ao sistema radicular possuir maior quantidade de transportadores, comparado às demais espécies (TAMAI; MA, 2003; TOKURA et al., 2011). A absorção do Si pelas raízes é realizada de forma ativa e na forma de ácido monossilícico $\mathrm{H}_{4} \mathrm{SiO}_{4}$ (MA et al., 2006). Devido à alta capacidade do arroz absorver o Si segundo Korndörfer et al. (1999) e Tokura (2011), em alguns casos, o teor na planta supera o de outros macronutrientes.

Após ser absorvido pela planta, o ácido monossilícico é transformado e polimerizado na forma de sílica amorfa $\mathrm{SiO}_{2} \cdot \mathrm{nH}_{2} \mathrm{O}$ nas paredes celulares da epiderme das folhas, colmos, cascas (RAVEN, 2003), idioblastos especializados também chamados de células de sílica e nos tricomas (MOTOMURA; FUJII; SUZUKI, 2001). Este processo ocorre conforme a água 
vai sendo perdida por transpiração (SANGSTER; HODSON; TUBB, 2001). Após a deposição do nutriente na planta, forma-se uma camada dupla de Si/cutícula e Si/celulose (RAVEN, 2003). Quando polimerizado na forma amorfa, o Si se torna pouco móvel ou imóvel, dependendo da concentração e estrutura da sílica dentro da planta (YOSHIDA; OHNISHI; KITAGISHI, 1962; FOX et al., 1969).

Se a quantidade de Si de diferentes partes de uma mesma planta for avaliada entre si, haverá maior presença do nutriente na parte aérea, em relação à raiz e maior teor nas folhas velhas em relação às novas, além da parte basal da folha possuir maior concentração de Si do que a parte apical (WIESE; NIKOLIC; RÖMHELD, 2007).

Os benefícios que o Si proporciona às plantas estão relacionados diretamente à camada dupla descrita por Raven, pois haverá uma proteção física, acarretando em redução da perda de água pela transpiração das plantas (BARBOSA FILHO et al., 2001), redução da intensidade de pragas (GOUSSAIN et al., 2002) e doenças de importância econômica (PRABHU; SANTOS; DIDONET, 2007; DATNOFF; RODRIGUES; SEEBOLD, 2007; REZENDE et al., 2009) ou induzir a formação de compostos, ligados diretamente à defesa da planta, formando uma barreira química como a produção de fenóis (RODRIGUES et al., 2003) e resistência ao acamamento, tornando as plantas mais eretas, resultando também na melhoria da eficiência fotossintética (GAO et al., 2004; ÁVILA et al., 2010) em função da menor abertura do angulo foliar, o que permite uma maior captação da energia luminosa. Portanto, os efeitos do Si em plantas de arroz conferem melhores condições morfofisiológicas à planta, especialmente quando estas estão submetidas a estresse biótico ou abiótico (MA et al., 2004, 2006).

Apesar de o Si ser um dos elementos mais abundantes na superfície terrestre, representando $27 \%$ da crosta (HAVLIN et al., 1985), no solo, este nutriente pode ocorrer em quantidades bem reduzidas disponíveis às plantas. Cultivos intensivos e com alta exportação de Si, como as gramíneas em geral, podem reduzir rapidamente o teor desse elemento no solo, especialmente em solos de regiões tropicais, os quais são caracterizados pelo alto grau de intemperismo, que contribui ao processo de dessilicatização (KORNDÖRFER et al., 2002). Consequentemente, a tendência é de redução da disponibilidade de nutrientes e argilas de baixa capacidade de troca de cátions com o passar do tempo (CASAGRANDE et al., 2003), devido às alterações estruturais e químicas dos minerais de argila (BARBOSA FILHO et al., 2001; FAGERIA; BALIGAR; JONES, 2011), somado ao fato de que estes solos também possuem elevadas quantidades de óxidos de alumínio e ferro (MALAVOLTA, 2006), os quais são responsáveis pela adsorção do Si. 
De acordo com Foy (1992), em solos das regiões de clima temperado, os teores de $\mathrm{SiO}_{2}$ são maiores do que os sesquióxidos de ferro e alumínio, ocorrendo o inverso nas regiões tropicais. As principais formas do Si no solo estão distribuídas em: solúvel na forma de ácido silícico $\left(\mathrm{H}_{4} \mathrm{SiO}_{4}\right)$, polimerizado e de pouca absorção pelas plantas, $\mathrm{Si}$ adsorvido com $\mathrm{Fe}, \mathrm{Al}$ e Mn e minerais silicatados não disponíveis as plantas (KORNDÖRFER; PEREIRA; NOLLA, 2004).

Através da interação nos óxidos, devido à similaridade química entre as formas aniônicas de $\mathrm{P}$ e Si, $\mathrm{H}_{2} \mathrm{PO}_{4}{ }^{-}$e $\mathrm{H}_{3} \mathrm{SiO}_{4}{ }^{-}$(MCKEAGUE; CLINE, 1963 e HINGSTON et al., 1972), pode ocorrer a saturação dos sítios de adsorção por Si e/ou P, o que pode impedir a formação dos complexos de superfície entre os óxidos de $\mathrm{Fe}$ e Al, deixando o Si ou P disponível às plantas (CARVALHO, 2000).

Apesar do Si disponível no solo ocorrer predominantemente na forma de acido monossilícico $\left(\mathrm{H}_{4} \mathrm{SiO}_{4}\right)$, existem varias formas que podem influenciar o teor deste elemento no solo: por meio da utilização de fertilizantes, liberação do $\mathrm{Si}$ presentes nos óxidos e hidróxidos de ferro e alumínio, decomposição de materiais vegetais, água utilizada para irrigação e dissoluções do ácido silícico polimérico e dos minerais cristalinos e não cristalinos.

As principais formas de saída do Si do solo podem ocorrer pela absorção e exportação da planta, lixiviação, e adsorção por óxidos e hidróxidos de ferro e alumínio em função do teor de argila do solo. Também pode haver perdas por formação de polímeros de Si e de minerais cristalinos (SAVANT et al., 1997).

\subsubsection{Interação entre Si e P}

$\mathrm{Na}$ literatura já são conhecidos dados indicando a interação entre o P e Si, os quais competem entre si pelos mesmos sítios de adsorção no solo, fazendo com que um possa deslocar o outro, tornando-o mais disponíveis às plantas (OBIHARA; RUSSEL, 1972; OLIVEIRA, 1984; LEITE, 1997). Justificativas para a este efeito entre os dois elementos ainda são bastante discutidas.

A forma mais comum do $\mathrm{Si}$ no solo, $\mathrm{H}_{4} \mathrm{SiO}_{4}$, pode ficar retida no solo, de maneira semelhante ao que ocorre com o íon fosfato (HINGSTON et al., 1972). Holt e King (1955) verificaram por meio do radioisótopo ${ }^{31} \mathrm{Si}$, que esse elemento era adsorvido por adsorção específica às superfícies dos óxidos de Fe. Segundo McKeague e Cline (1963) e Hingston et al. (1972), a similaridade química de duas formas aniônicas de $\mathrm{P}$ e Si, $\mathrm{H}_{2} \mathrm{PO}_{4}^{-}$e $\mathrm{H}_{3} \mathrm{SiO}_{4}{ }^{-}$, explica os resultados positivos da interação entre Si e P. 
Camargo et al. (2003) demonstraram que em solos intemperizados pode haver aumento do aproveitamento do $\mathrm{P}$ pelas plantas quando submetidas a aplicação de Si. De acordo com Ma et al. (1991), neste processo ocorre a substituição parcial do P que está presente no solo pelo $\mathrm{Si}$, tornando-o mais disponível à planta.

Smyth e Sanchez (1980) também relaram que há incremento da disponibilidade e no aproveitamento do P nas plantas pela aplicação de Si . Savant et al. (1999) atribuiram a este processo o efeito indireto do aumento do $\mathrm{pH}$, bloqueando os sítios de adsorção com a utilização de silicato, reduzindo a adsorção do fosfato, pois há evidências de que competem pelo mesmo sítio de adsorção, como descrito acima.

Baldeon (1995) avaliou a competição entre P e Si, na eficiência do termofosfato magnesiano, no qual observou a superioridade desta fonte, quando comparado com o superfosfato triplo, independente da correção do solo. Este resultado foi atribuído à competição entre os dois elementos, combinada com a ação alcalinizante do termofosfato.

Trabalhos com eucalipto têm demonstrado que o Si é capaz de realizar a dessorção do $\mathrm{P}$, principalmente em solos menos intemperizados. Assim, o efeito do $\mathrm{Si}$ no crescimento vegetal parece estar associado com as reações desse elemento com o P no solo e na planta (Carvalho et al. 2001).

Em virtude da importância da adubação fosfatada para as plantas, muitos pesquisadores tem buscado avaliar a interação do $\mathrm{Si}$ com o $\mathrm{P}$, a fim de se esclarecer e melhorar a eficiência da adubação fosfatada.

\subsubsection{Utilização do radioisótopo ${ }^{32} \mathbf{P}$}

A utilização de radioisótopos como traçadores na agricultura, no caso do isótopo de $\mathrm{P}$, permite a determinação da fonte do nutriente (solo ou fertilizante) que foi absorvido pela planta. Também possibilita a quantificação através de cálculos, do fósforo proveniente do fertilizante (\%Pppf) e do solo (\%Ppps) (FARDEU; GUIRAUD; MAROL, 1996).

Com o uso do ${ }^{32} \mathrm{P}$, permite-se avaliar os efeitos dos tratamentos, mesmo que não haja diferença nas respostas sendo esta a grande vantagem do uso da técnica de diluição isotópica (MURAOKA, 1991). O radioisótopo ${ }^{32} \mathrm{P}$ é utilizado em estudos de fertilidade do solo e ciclagem de nutriente, contribuindo enormemente em pesquisas no Brasil (MURAOKA, 1991; FERNANDES; MURAOKA, 2002; FRANZINI; MURAOKA; MENDES, 2009).

Na natureza, $100 \%$ do $\mathrm{P}$ existente está na forma de ${ }^{31} \mathrm{P}$, sendo que todos seus isótopos são sintetizados pelo homem. O principal fator que determina a viabilidade do uso do isótopo é a meia vida, que pode ser definida como o tempo gasto para que a atividade de uma 
determinada quantidade de material radioativo se reduza à metade de seu valor inicial. $\mathrm{O}{ }^{33} \mathrm{P}$ possui meia vida de 25,3 dias, enquanto que o ${ }^{32} \mathrm{P}$ leva 14,3 dias para decair a metade da quantidade inicial. Por esta característica, apesar da possibilidade do uso do ${ }^{33} \mathrm{P}$ ser mais prolongado, no Brasil, a maior parte dos estudos com planta e solo utiliza o ${ }^{32} \mathrm{P}$, em virtude do baixo custo de produção e da dificuldade de importação do ${ }^{33} \mathrm{P}$.

$\mathrm{O}{ }^{32} \mathrm{P}$ emite partículas beta $(\beta)$, considerada de alta energia $(1,71 \mathrm{MeV})$ e representa um perigo considerável, exigindo cuidados adicionais no seu manuseio, porém, tem a vantagem de ser detectada por efeito Cerenkov em detector de cintilação em meio líquido, dispensando o uso de solução cintiladora. $\mathrm{O}$ efeito Cerenkov é produzido quando as partículas $\beta$-, com energia superior a $0,263 \mathrm{MeV}$, passam por meio aquoso adquirem velocidade maior que a velocidade da luz naquele meio (VOSE, 1980).

Diversos trabalhos e informações foram obtidos utilizando-se da metodologia isotópica $\left({ }^{32} \mathrm{P}\right)$ em relação à dinâmica do $\mathrm{P}$ no sistema solo planta (NEPTUNE; MURAOKA; STEWART, 1979; MURAOKA, 1983; FAQUIN; MALAVOLTA; MURAOKA, 1990), nos quais os autores observaram que raramente a eficiência de determinados fertilizantes fosfatados, é superior a 10\%, contrariando a eficiência teórica normalmente considerada nos cálculos de adubação.

De acordo com Chien, Menon e Billingham (1996), o uso de ${ }^{32} \mathrm{P}$ é imprescindível quando se pretende avaliar a eficiência de fertilizantes fosfatados. $\mathrm{O}$ grande benefício desta técnica, com o uso do radioisótopo é a possibilidade de determinar na planta o $\mathrm{P}$ proveniente do solo ou que veio do fertilizante.

\subsection{Material e Métodos}

\subsubsection{Caracterização do solo utilizado nos experimentos}

Para o desenvolvimento deste projeto, foram conduzidos três experimentos utilizandose o mesmo solo, coletado na camada entre 0 - $20 \mathrm{~cm}$, classificado como Latossolo Vermelho Amarelo distrófico (EMBRAPA, 2013), localizada no Campus da Escola Superior de Agricultura "Luiz de Queiroz" (ESALQ), município de Piracicaba - SP. O solo foi peneirado utilizando-se peneiras com abertura de $4 \mathrm{~mm}$ e seco ao ar.

O solo apresenta 171, 69 e $760 \mathrm{~g} \mathrm{~kg}^{-1}$ de argila, silte e areia (CAMARGO; MONIZ; VALADARES, 1986). As propriedades químicas foram determinadas de acordo com os métodos analíticos descritos por Raij et al. (2001) (Tabela 1). 
Tabela 1 - Caracterização das propriedades químicas do solo utilizado nos experimentos.

\begin{tabular}{|c|c|c|c|c|c|c|c|c|c|c|}
\hline $\mathrm{pH}$ & $\mathrm{MO}$ & $\mathrm{P}$ & $\mathrm{K}$ & $\mathrm{Ca}$ & $\mathrm{Mg}$ & $\mathrm{H}+\mathrm{Al}$ & SB & CTC & $\mathrm{Si}$ & $\mathrm{V}$ \\
\hline $\mathrm{CaCl}_{2}$ & $\mathrm{~g} \mathrm{dm}^{-3}$ & $\mathrm{mg} \mathrm{dm}^{-3}$ & - & -- & -- & $\mathrm{nol}_{\mathrm{c}} \mathrm{dm}^{-}$ & & 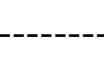 & $\mathrm{mg} \mathrm{dm}^{-3}$ & $\%$ \\
\hline 5,4 & 16 & 13 & 1 & 23 & 9 & 20 & 33 & 53 & 4 & 62 \\
\hline
\end{tabular}

\subsubsection{Caracterização da fonte de fósforo}

A fonte de P utilizada neste estudo foi o superfosfato triplo (SFT), marcado com ${ }^{32} \mathrm{P}$ (marcação direta) com atividade de $550 \mathrm{MBq}$ (megabecquerel), como fonte de $\mathrm{P}$ padrão. $\mathrm{O}$ teor de $\mathrm{P}$ total $(19,2 \%)$ e $\mathrm{P}_{2} \mathrm{O}_{5}$ solúvel em $\mathrm{CNA}+\mathrm{H}_{2} \mathrm{O}$ (43\%) foi determinado de acordo com a metodologia oficial do Ministério da Agricultura Pecuária e Abastecimento (MAPA, 2007). De acordo com esta metodologia, o teor total indica o potencial de fósforo em qualquer fertilizante, enquanto que o teor solúvel em $\mathrm{CNA}+\mathrm{H}_{2} \mathrm{O}$, é utilizado para avaliar o $\mathrm{P}$ disponível para as plantas.

\subsubsection{Caracterização da fonte de silício}

Foram utilizadas duas fontes: (i) Wollastonita, que é um silicato de cálcio natural com alto teor de pureza, sendo comumente utilizada em diversos estudos como padrão para experimentos com este elemento; (ii) Microton (filossilicato), que é uma fonte comercial caracterizada pela mistura de filossilicatos e também é uma fonte natural.

Os teores de Si total foram determinados segundo metodologia de Korndörfer, Pereira e Nolla, (2004) e as fontes apresentaram, respectivamente, 21 e $26 \%$ de Si na wollastonita e filossilicato.

\subsubsection{Diluição isotópica do ${ }^{32} \mathbf{P}$}

O P na planta proveniente do fertilizante (Pppf) e o aproveitamento do nutriente do SFT foram calculados de acordo com as equações a seguir (VOSE, 1980):

$\% P p p f=\frac{A E \text { pianta }}{A E \text { fertilizanta }} \times 100$

$A E$ planta $=\frac{32 P \text { planta }}{31 P \text { planta }}$ 
AE fertilizante $=\frac{32 F S F T}{31 F S F T}$

O Pppf em quantidade é obtido pela fórmula:

$Q P p p f=\frac{\% \text { Pppf } x P \text { total }}{100}$

Onde:

$\% \mathrm{Pppf}=$ porcentagem do fósforo na planta proveninente do fertilizante

AE planta $=$ Atividade específica do fósforo na planta

AE fertilizante $=$ Atividade específica do superfosfato triplo

P total $=$ Fósforo absorvido

O aproveitamento (AP) de P aplicado é obtido por:

$$
A P=\frac{\text { QPppf }}{\text { Q aplicado }} \times 100
$$

Onde:

Q Pppf = quantidade de fósforo na planta proveniente do superfosfato triplo $\mathrm{Q}$ aplicado = quantidade de fósforo aplicado no solo

\subsubsection{Experimentos}

Em dois, dos três experimentos, utilizou-se a cultura do arroz (Oryza sativa L.) como planta teste e no terceiro experimento foi realizada incubação do solo (sem planta). Todos os experimentos foram conduzidos em casa-de-vegetação do Laboratório de Fertilidade do Solo do Centro de Energia Nuclear na Agricultura, no município de Piracicaba - SP.

\subsubsection{Experimento 1: Efeito das doses de silício no aproveitamento do fósforo do superfosfato triplo pelo arroz}

O experimento foi realizado em vasos de polietileno revestidos com sacos plásticos contendo $3 \mathrm{~kg}$ de terra (Tabela 1). Os vasos foram distribuídos na bancada em esquema 
fatorial e delineamento inteiramente casualizado (DIC), com duas fontes de silício, seis doses e quatro repetições (Tabela 2).

A acidez do solo foi corrigida com calcário dolomítico (PRNT $=90 \%)$, baseado na dose mais alta da wollastonita, tendo em vista que uma das características deste material é elevar o pH do solo, reagindo de forma similar ao calcário no solo (ALCARDE, 1992).

Para a outra fonte de $\mathrm{Si}$, a base de filossilicatos, por não possuir esta característica neutralizante, foi aplicado o calcário na dose correspondente ao poder de correção da wollastonita, para que não houvesse interferência do $\mathrm{pH}$ entre elas.

Ambas as fontes de $\mathrm{Si}$ foram peneiradas utilizando-se peneira de 50 mesh (malhas/polegada).

Tabela 2 - Tratamentos de fontes de silício (Si) e doses aplicadas no solo.

\begin{tabular}{ccc}
\hline Tratamento & Fonte de silício & Dose de silício \\
\hline 1 & & $\mathrm{mg} \mathrm{dm}^{-3}$ \\
2 & Controle & 0 \\
3 & Wollastonita & 50 \\
4 & Wollastonita & 100 \\
5 & Wollastonita & 150 \\
6 & Wollastonita & 200 \\
7 & Wollastonita & 250 \\
8 & Controle & 0 \\
9 & Filossilicato & 50 \\
10 & Filossilicato & 100 \\
11 & Filossilicato & 150 \\
12 & Filossilicato & 200 \\
\hline
\end{tabular}

Juntamente com as fontes de $\mathrm{Si}$, foi aplicado o superfosfato triplo marcado com ${ }^{32} \mathrm{P}$ (marcação direta) na dose de $53 \mathrm{mg} \mathrm{kg}^{-1}$. Ambos fertilizantes foram misturados ao solo através da agitação dos sacos plásticos contidos nos vasos. A marcação do fertilizante fosfatado foi realizada de forma direta, na qual o superfosfato triplo foi umedecido com água deionizada e recebeu a solução com $550 \mathrm{Mbq}$ de ${ }^{32} \mathrm{P}$ livre de carregador.

Após a aplicação dos fertilizantes fosfatados e silicatados, o solo permaneceu em repouso por aproximadamente 30 dias, mantendo-se a umidade próximo de $70 \%$ da capacidade máxima de retenção, a fim de se permitir a reação dos fertilizantes com o solo.

Foram semeadas seis sementes de arroz da cultivar IAC 203 por vaso, e realizado o desbaste das plântulas duas semanas após a emergência. 
A partir da interpretação da análise de solo verificou-se que apenas o boro e molibdênio dos micronutrientes e potassio dos macronutrientes estavam abaixo dos teores adequados no solo. Sendo assim, foi realizada uma adubação parcelada aos 15 e 30 dias, com nitrogênio e potássio aplicados nas doses de $150 \mathrm{mg} \mathrm{kg}^{-1}$ de $\mathrm{N}$ na forma de uréia, $150 \mathrm{mg} \mathrm{kg}{ }^{-1}$ de K como cloreto de potássio. A adubação com micronutrientes (B e Mo) foi realizada com aplicação de $10 \mathrm{~mL} \mathrm{vaso}^{-1}$ de uma solução nutritiva. Aos 30 dias, as plantas foram pulverizadas com inseticida composto de deltrametrina, para evitar infestação de pragas.

A parte aérea das plantas de arroz foi cortada aos 50 dias após a semeadura e secas em estufa com circulação forçada de ar a $60^{\circ} \mathrm{C}$ por três dias, posteriormente foram pesadas para determinação da matéria seca da parte aérea (MSPA) e moídas em moinho tipo Willey.

$\mathrm{O}$ material foi submetido à digestão nitroperclórica e a atividade do ${ }^{32} \mathrm{P}$ determinada em aparelho de cintilação em meio líquido, pelo efeito Cerenkov (VOSE, 1980). A concentração de P na planta foi determinada através da metodologia elaborada por Sarruge e Haag (1974) e o P acumulado foi calculado considerando a MSPA.

A quantidade de $\mathrm{P}$ na planta proveniente do fertilizante (Pppf) e o aproveitamento do fertilizante (AP) foram calculados a partir do método de diluição isotópica, descrito acima.

Para o teor de silício na planta, foi realizada a digestão com peróxido de hidrogênio $\left(\mathrm{H}_{2} \mathrm{O}_{2}\right)$, através do método amarelo descrito por (ELLIOT et al., 1991).

$\mathrm{O}$ teor de $\mathrm{P}$ no solo foi determinado através da extração realizada pelo método da resina (RAIJ et al., 2001). E o teor de Si foi determinado por dois extratores, cloreto de cálcio e ácido acético (KORNDÖRFER et al., 2004).

Os dados de MSPA, P e Si acumulado na planta, Pppf e AP e os teores de P e Si disponíveis no solo foram submetidos à ANOVA, ajustados modelos de regressão para análise do efeito de doses e as médias comparadas entre si pelo teste de Tukey ( $p<0,05)$, através do software SAS (SAS Institute, 1996).

\subsubsection{Experimento 2: Formas de aplicação de silício e fósforo no aproveitamento do $P$ do superfosfato triplo pelo arroz}

O experimento foi desenvolvido em vasos de polietileno revestidos com sacos plásticos contendo $2,0 \mathrm{~kg}$ de terra (Tabela 1) e distribuidos sob a bancada em esquema fatorial com delineamento inteiramente casualizado (DIC), com duas fontes de silício, quatro formas de aplicação e quatro repetições. 
A dose de $\mathrm{P}$ foi similar ao experimento 1 (53 $\left.\mathrm{mg} \mathrm{kg}^{-1}\right)$ na forma de superfosfato triplo, marcado com ${ }^{32} \mathrm{P}$ e a dose de silício foi de $125 \mathrm{mg} \mathrm{dm}^{-3}$, sendo a dose intermediária daquelas que foram aplicadas no experimento 1.

$\mathrm{O}$ pH do solo também foi corrigido com calcário (PRNT $=90 \%$ ), baseado na dose mais alta da wollastonita, para que não houvesse interferência do $\mathrm{pH}$ entre elas. Ambas as fontes de Si foram peneiradas utilizando-se peneira de 50 mesh (malhas/polegada).

Os tratamentos, que correspondem às formas de aplicação do Si estão descritos na tabela 3. No tratamento controle foi aplicado apenas o P, sem aplicação de Si. Sendo que nos demais, as fontes silicatadas foram aplicadas juntamente com o superfosfato triplo.

Tabela 3 - Tratamentos de fontes de silício (Si) e formas de aplicação no solo.

\begin{tabular}{ccc}
\hline Tratamento & Fonte de silício & Forma de aplicação \\
1 & Controle & Localizado \\
2 & Controle & Área total \\
3 & Wollastonita & Localizado \\
4 & Wollastonita & Área total \\
5 & Filossilicato & Localizado \\
6 & Filossilicato & Área total \\
\hline
\end{tabular}

Os demais procedimentos foram seguidos como no experimento 1. Após a aplicação dos fertilizantes fosfatados e silicatados, o solo permaneceu em repouso por aproximadamente 30 dias, mantendo-se a umidade do solo próximo de $70 \%$ da capacidade máxima de retenção, a fim de se permitir a reação dos fertilizantes com o solo.

Foram semeadas seis sementes de arroz, cultivar IAC 203, por vaso e as plântulas desbastadas depois de duas semanas após a emergência, a fim de se desenvolver duas plantas por vaso.

Foram aplicados os nutrientes N, K, B e Mo assim como inseticida, conforme já relatado no experimento 1 .

Os dados de MSPA, P e Si acumulado na planta, Pppf e AP e os teores de P e Si disponíveis no solo foram submetidos à ANOVA e as médias comparadas entre si pelo teste de Tukey ( $\mathrm{p}<0,05)$, através do software SAS (SAS Institute, 1996). 


\subsubsection{Experimento 3: Incubação do solo após a aplicação de fósforo e doses de silício}

O experimento foi desenvolvido em potes revestidos com sacos plásticos contendo $0,5 \mathrm{~kg}$ de terra (Tabela 1 ) e distribuídos sob a bancada em esquema fatorial com delineamento inteiramente casualizado (DIC), com duas fontes de silício, seis doses e quatro repetições.

Juntamente com as fontes de silício, foi aplicado o superfosfato triplo marcado com ${ }^{32} \mathrm{P}$ (marcação direta) na dose de $53 \mathrm{mg} \mathrm{kg}^{-1}$ e ambos fertilizantes foram homogeneizados ao solo através da agitação dos sacos plásticos. A marcação do fertilizante fosfatado foi realizada de forma direta, na qual o superfosfato triplo foi umedecido com água deionizada e recebeu a solução com $550 \mathrm{MBq}$ de ${ }^{32} \mathrm{P}$ livre de carregador.

As doses de Si adicionadas ao solo foram baseadas no teor de Si total das fontes. Os tratamentos estão descritos na Tabela 4.

Tabela 4 - Tratamentos de doses e fontes de silício (Si) aplicados para incubação do solo.

\begin{tabular}{ccc}
\hline Tratamento & Fonte de silício & Dose de silício \\
\hline 1 & & $\mathrm{mg} \mathrm{dm}^{-3}$ \\
2 & Controle & 0 \\
3 & Wollastonita & 50 \\
4 & Wollastonita & 100 \\
5 & Wollastonita & 150 \\
6 & Wollastonita & 200 \\
7 & Wollastonita & 250 \\
8 & Controle & 0 \\
9 & Filossilicato & 50 \\
10 & Filossilicato & 100 \\
11 & Filossilicato & 150 \\
12 & Filossilicato & 200 \\
\hline
\end{tabular}

Foi realizada mensalmente a coleta, aos 0, 30, 60 e 90 dias após a aplicação das fontes de silício. Procurou-se manter a umidade próximo de $70 \%$ da capacidade máxima de retenção, a fim de se permitir a reação dos fertilizantes com o solo. Os teores de P no solo foram analistados através do extrator resina e o Si via ácido acético e cloreto de cálcio.

Os dados de $\mathrm{P}$ e Si disponíveis no solo foram ajustados modelos de regressão para análise do efeito do tempo, em relação a cada uma das doses utilizadas. No tempo 0 , também foi analisado o efeito de doses, os quais foram submetidos à ANOVA e as médias comparadas entre si pelo teste de Tukey ( $\mathrm{p}<0,05)$, através do software SAS (SAS INSTITUTE, 1996). 


\subsection{Resultados e Discussão}

\subsubsection{Experimento 1: Efeito das doses de silício no aproveitamento do fósforo do superfosfato triplo pelo arroz}

Verificou-se que a MSPA do arroz aumentou em função das doses de Si aplicadas, que variaram de 0 a $250 \mathrm{mg} \mathrm{dm}^{-3}$, se ajustando linearmente para a wollastonita e exponencialmente para a fonte de filossilicato (Figura 1).

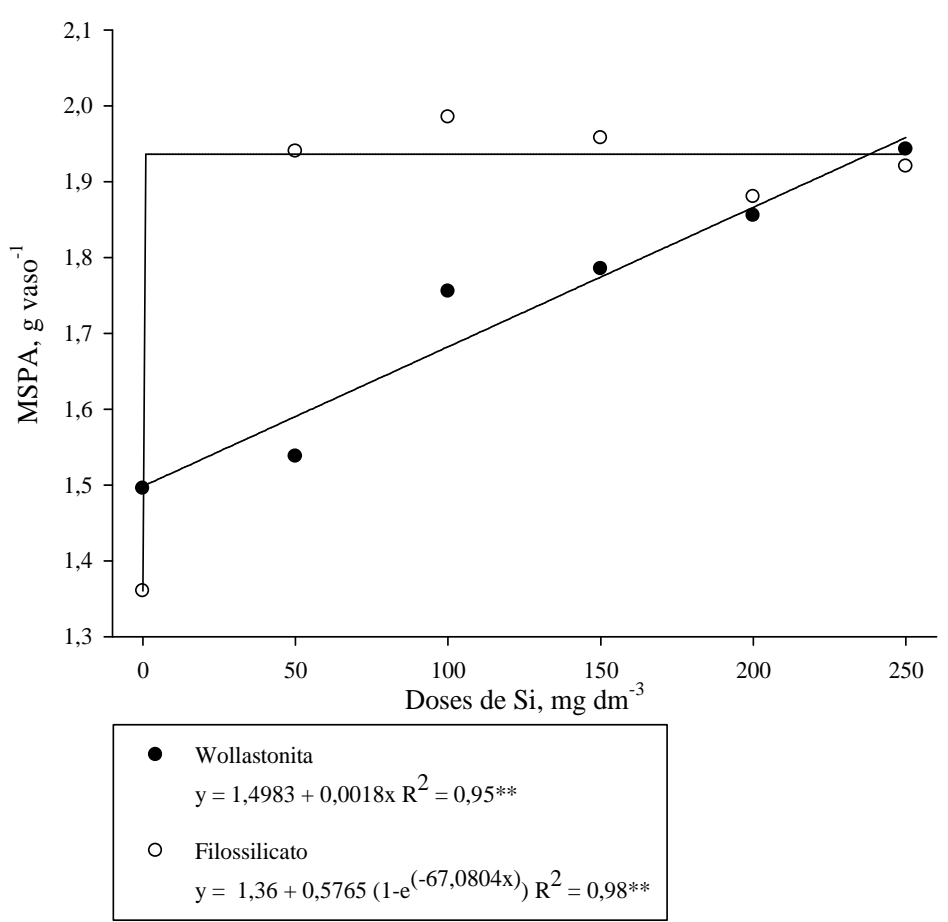

Figura 1 - Efeito de fontes e doses de silício na produção de massa seca da parte aérea (MSPA) de arroz.

Entretanto, mesmo com os dados obtidos terem se ajustado a uma regressão linear, as plantas submetidas à aplicação da wollastonita não obtiveram incrementos significativos em seu crescimento quando comparadas pelo teste de médias, independente da dose utilizada. Com o filossilicato, os ganhos de MSPA foram significativos em relação ao tratamento controle quando comparado com as demais doses de Si (Tabela 5).

Faria Junior et al. (2009), trabalhando com cultivares de arroz de sequeiro (Conai e Curinga) em casa de vegetação, estudaram a wollastonita como fonte de Si nas doses que 
variaram entre 500 e $2000 \mathrm{~kg} \mathrm{ha}^{-1}$. Os autores concluíram que as doses de Si para esta fonte não influenciaram os componentes de crescimento e produção do arroz. Mauad et al. (2003), em trabalho com arroz (IAC202), e utilizando a wollastonita como fonte de Si, testaram as doses variando de 0 a $560 \mathrm{~kg} \mathrm{ha}^{-1}$ e não constataram o efeito do Si na produção da parte aérea da planta.

Incremento de produção de matéria seca de Braquiarinha (B. decumbens) foi verificado pela aplicação de $2000 \mathrm{~kg} \mathrm{ha}^{-1}$ de Si via fonte wollastonita (KORNDÖRFER; ABDALA; BUENO 2001).

Ao contrario do resultado encontrado neste trabalho, Mauad, Crusciol e Grassi Filho (2011) não obtiveram aumentos significativos de massa de matéria seca da parte aérea do arroz utilizando o ácido silícico como fonte e variando as doses entre 0 e $350 \mathrm{~kg} \mathrm{ha}^{-1} \mathrm{de} \mathrm{Si}$ plantas de arroz de sequeiro (Caiapó) e sistema irrigado (Maravilha),

Tabela 5 - Produção de massa seca da parte aérea (MSPA) $\left(\mathrm{g} \mathrm{vaso}^{-1}\right)$ em função de fontes de doses de silício (Si).

$$
\text { Doses de } \mathrm{Si}\left(\mathrm{mg} \mathrm{dm}^{-3}\right)
$$

\begin{tabular}{ccccccc} 
Fontes de $\mathrm{Si}$ & 0 & 50 & 100 & 150 & 200 & 250 \\
& $\ldots \ldots \ldots \ldots \ldots \ldots \ldots$ & & MSPA $\left.(\mathrm{g} \mathrm{vaso})^{-1}\right)$ \\
Wollastonita & $1,50 \mathrm{aA}$ & $1,54 \mathrm{aB}$ & $1,76 \mathrm{aA}$ & $1,79 \mathrm{aA}$ & $1,86 \mathrm{aA}$ & $1,94 \mathrm{aA}$ \\
Filossilicato & $1,36 \mathrm{bA}$ & $1,94 \mathrm{aA}$ & $1,99 \mathrm{aA}$ & $1,82 \mathrm{aA}$ & $1,88 \mathrm{aA}$ & $1,92 \mathrm{aA}$ \\
\hline $\mathrm{CV}(\%)$ & 15,05 & & &
\end{tabular}

Letras minúsculas iguais na linha e maiúsculas na coluna não diferem entre si pelo teste de Tukey a 5\%

Foi verificada diferença entre wollastonita e filossilicato apenas para a dose baixa (50 $\mathrm{mg} \mathrm{dm}{ }^{-3}$ ), sendo que não houve diferença entre as duas fontes de Si para as demais doses estudas (Tabela 5).

O resultado obtido no presente estudo corrobora com os resultados observados por Sandim (2012), a qual avaliou três fontes de Si inclusive com a wollastonita, a mesma utilizada neste experimento. A dose de $\mathrm{P}\left(50 \mathrm{mg} \mathrm{dm}^{-3}\right)$ utilizada pela autora foi similar a utilizada no presente estudo $\left(53 \mathrm{mg} \mathrm{dm}^{-3}\right)$. De acordo com a autora, em um solo de textura média, a aplicação da wollastonita não incrementou a quantidade de massa seca produzida pelo milho quando comparado ao tratamento controle (sem $\mathrm{Si}$ ), enquanto que outras duas fontes (escória de aciaria e de forno de panela) apresentaram aumentos na massa seca das plantas. 
Dados encontrados na literatura demonstram que fontes comerciais de diversos tipos, apresentam resultados melhores do que a fonte padrão (wollastonita), quando é analisado o ganho de produção para a cultura do arroz. Este comportamento também foi observado no presente estudo.

Foi verificado aumento no $\mathrm{P}$ acumulado na planta em função das doses de wollastonita e do filossilicato. Os resultados de $\mathrm{P}$ acumulado ajustaram significativamente às equações quadrática e exponencial para as duas fontes avaliadas. Os dados referentes à wollastonita ajustaram em uma regressão quadrática, enquanto que para o filossilicato, a curva se comportou de modo exponencial, em função das doses de Si aplicadas no solo (Figura 2).

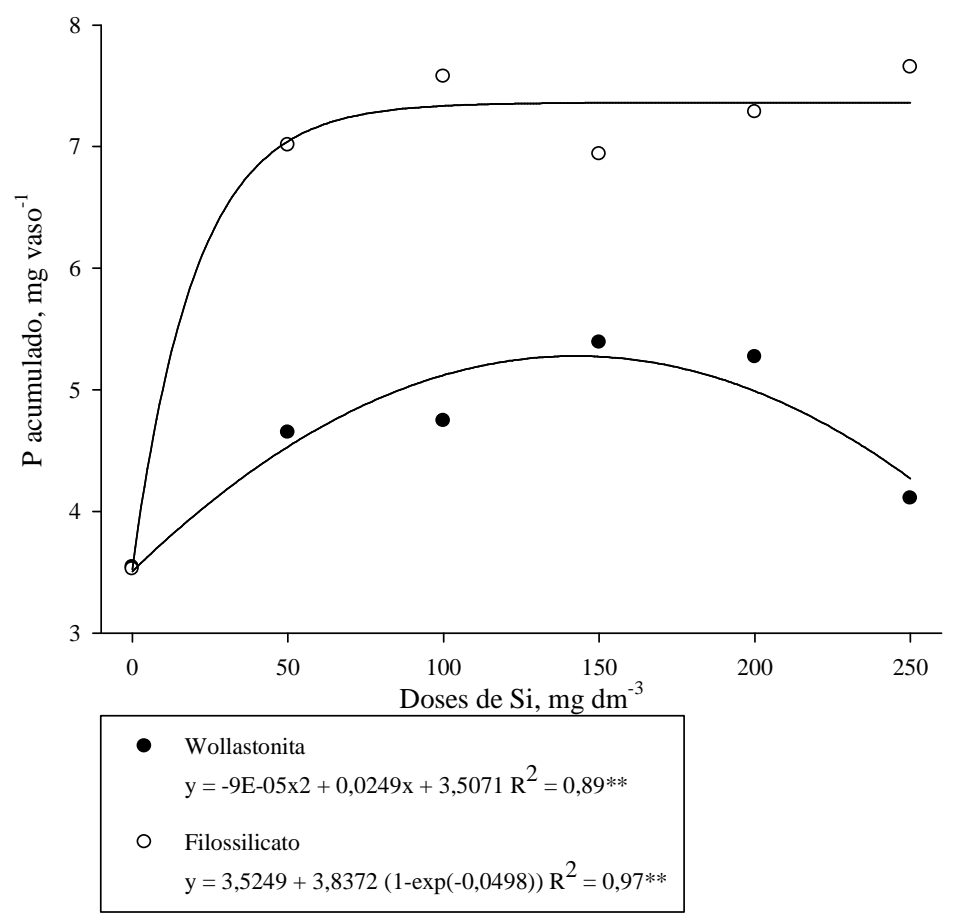

Figura 2 - Efeito de fontes e doses de silício ( $\mathrm{Si}$ ) no fósforo $(\mathrm{P})$ acumulado na massa seca da parte aérea de arroz.

O P acumulado na planta também variou de acordo com a fonte de Si utilizada. Entre as fontes, a resposta foi consideravelmente maior no filossilicato quando comparado com a wollastonita, apresentando diferença significativa nas doses 50,100 e $250 \mathrm{mg} \mathrm{dm}^{-3}$. Na tabela 6, observa-se que mesmo na menor dose de Si aplicada, houve alteração significativa no P acumulado na planta, pelo teste de médias, quando submetida à aplicação do filossilicato em relação à wollastonita. $\mathrm{O}$ comportamento dos dados ocorreu de forma similar aos encontrados 
para a variável MSPA (Tabela 5), indicando que o fato do filossilicato ter contribuído para maior absorção de P, ocasionou em ganhos na MSPA.

Tabela 6 - Fósforo (P) acumulado na parte aérea do arroz em função de fontes de doses de silício $(\mathrm{Si})$.

\begin{tabular}{|c|c|c|c|c|c|c|}
\hline \multirow[b]{2}{*}{ Fontes de $\mathrm{Si}$} & \multicolumn{6}{|c|}{ Doses de $\mathrm{Si}\left(\mathrm{mg} \mathrm{dm}^{-3}\right)$} \\
\hline & 0 & 50 & 100 & 150 & 200 & 250 \\
\hline & \multicolumn{6}{|c|}{$\mathrm{P}$ acumulado (mg vaso $\left.{ }^{-1}\right)$} \\
\hline Wollastonita & $2,94 \mathrm{aA}$ & $4,04 \mathrm{aB}$ & 4,04 aB & $4,68 \mathrm{aA}$ & $4,53 \mathrm{aA}$ & $3,32 \mathrm{aB}$ \\
\hline Filossilicato & $2,93 \mathrm{bA}$ & $6,25 \mathrm{aA}$ & $6,80 \mathrm{aA}$ & $6,23 \mathrm{aA}$ & $6,55 \mathrm{aA}$ & $6,90 \mathrm{aA}$ \\
\hline $\mathrm{CV}(\%)$ & 15,71 & & & & & \\
\hline
\end{tabular}

Letras minúsculas iguais na linha e maiúsculas na coluna não diferem entre si pelo teste de Tukey a 5\%.

O resultado encontrado por Sandim (2012), a qual utilizou doses de P similar à utilizada neste trabalho e avaliou diferentes fontes de $\mathrm{Si}$, corrobora com o presente estudo em que a wollastonita foi menos eficiente em aumentar o $\mathrm{P}$ acumulado na MSPA das plantas, quando comparada com outras fontes de Si.

A ausência do efeito da aplicação de fontes silicatadas sobre os teores de macronutrientes em plantas de arroz também foi constatado em outros trabalhos por Carvalho (2000), Silva e Bohnen (2001) e Mauad (2001) para N, P, K, e Carvalho (2000) e Silva e Bohnen (2001) para Ca e Mg.

Apesar de o fornecimento de $\mathrm{P}$ pelas duas fontes silicatadas (filossilicato $\mathrm{e}$ wollastonita) não ser expressivo, pois estas contêm quantidades traço de P na sua composição, os resultados obtidos com a fonte de filossilicato demonstram uma provável interação entre o Si e o $\mathrm{P}$, independente da dose utilizada. Este comportamento pode estar relacionado à saturação dos sítios de adsorção de $\mathrm{P}$ nos colóides do solo. Os ânions provenientes da dissolução da fonte de filossilicato dificulta a fixação do $\mathrm{P}$ do fertilizante, pois compete pelo mesmo sítio ativo. Outra possível justificativa é a reversibilidade do P presentes nos colóides, com o Si das fontes silicatadas, tornando-o o íon fosfato novamente disponível para ser absorvido pelas plantas.

O P disponível no solo, analisado pela resina trocadora de íons apresentou comportamento destinto entre as fontes de $\mathrm{Si}$ avaliada. Utilizando-se a wollastonita, houve ajuste linear em função das doses (Figura 3). Em relação à fonte de filossilicato, verificou-se que não houve ajuste da regressão. 


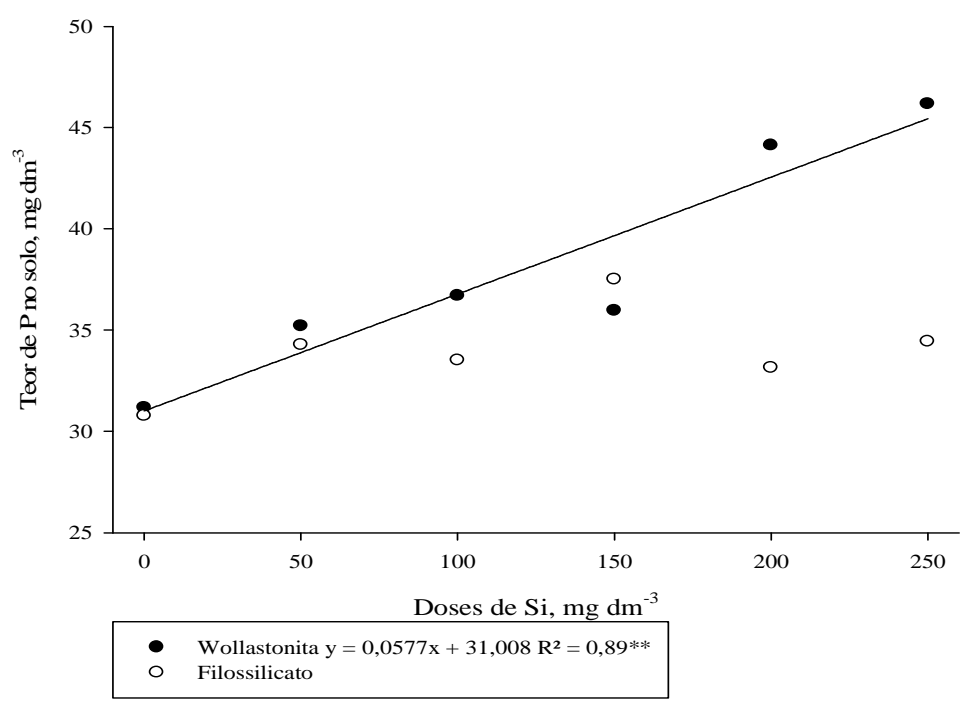

Figura 3 - Efeito de fontes e doses de silício ( $\mathrm{Si}$ ) no teor de fósforo (P) no solo extraído pela resina trocadora de íons $\left(\mathrm{mg} \mathrm{dm}^{-3}\right)$.

Ao se aplicar o teste de médias, verificou-se que o teor de $\mathrm{P}$ no solo extraído pela resina trocadora de íons, no tratamento com a aplicação de $\mathrm{Si}$ via wollastonita, foi significativamente maior quando se utilizou 200 e $250 \mathrm{mg} \mathrm{dm}^{-3}$ de Si. Já quando aplicado o filossilicato, verificou-se que não houve alteração significativa em nenhuma dose, inclusive em relação ao tratamento controle (sem Si) (Tabela 7). Entretanto, o comportamento semelhante das doses para a fonte filossilicato pode ser explicado por esta fonte de Si interagir com o P no solo em doses menores do que as utilizadas com a wollastonita, permitindo que o $\mathrm{P}$ permaneça na solução do solo para que a planta possa absorver este nutriente, pois quando submetidas à aplicação do filossilicato, elas absorveram maiores quantidades de P (Tabela 6), fazendo com que o teor de P no solo não alterasse.

Tabela 7 - Teor de fósforo (P) no solo extraído pela resina trocado de íons $\left(\mathrm{mg} \mathrm{dm}^{-3}\right)$ em função de fontes de doses de silício $(\mathrm{Si})$.

\begin{tabular}{ccccccc} 
& \multicolumn{7}{c}{ Doses de Si $\left(\mathrm{mg} \mathrm{dm}^{-3}\right)$} \\
Fontes de Si & 0 & 50 & 100 & 150 & 200 & 250 \\
& $\ldots$ & \multicolumn{7}{c}{ Teor de P no solo $\left(\mathrm{mg} \mathrm{dm} \mathrm{dm}^{-3}\right)$} \\
Wollastonita & $31,17 \mathrm{bA}$ & $35,21 \mathrm{abA}$ & $36,70 \mathrm{abA}$ & $35,97 \mathrm{abA}$ & $44,12 \mathrm{aA}$ & $46,17 \mathrm{aA}$ \\
Filossilicato & $30,77 \mathrm{aA}$ & $34,28 \mathrm{aA}$ & $33,51 \mathrm{aA}$ & $37,50 \mathrm{aA}$ & $33,15 \mathrm{aB}$ & $34,44 \mathrm{aB}$ \\
\hline CV $(\%)$ & 11,18 & & &
\end{tabular}


Ao comparar as fontes wollastonita e filossilicato, verificou-se que ocorreu diferença no incremento do teor de P no solo extraído pela resina apenas nas doses mais altas (200 e $250 \mathrm{mg} \mathrm{dm}^{-3} \mathrm{de} \mathrm{Si}$ ), sendo que o maior teor de $\mathrm{P}$ foi obtido quando utilizada a wollastonita. Tal comportamento pode indicar que esta fonte de Si auxiliou na dessorção do $\mathrm{P}$ ou evitou a fixação do $\mathrm{P}$ do superfosfato triplo à fase sólida do solo, em função da alta concentração de $\mathrm{Si}$ disponibilizado pela wollastonita nas maiores doses avaliadas, sugerindo uma interação do tipo sinergia entre os dois elementos.

Entretanto, o maior teor de $\mathrm{P}$ no solo nos tratamentos que receberam silicatos também pode ser explicado devido ao somatório de dois efeitos: o poder alcalinizante do Si e a competição Si x P pelos mesmos sítios de adsorção dos solos (SANDIM, 2012), pois com a elevação do pH, ocorre aumento da solubilidade dos fosfatos de ferro e alumínio e aumento da concentração de $\mathrm{OH}^{-}$na solução do solo, reduzindo a adsorção do fosfato na fase sólida do solo (CASAGRANDE; CAMARGO, 1997).

Carneiro et al. (2006) observaram uma diminuição do teor de P no solo em função da adição de $\mathrm{Si}$, que poderia ter sido ocasionada pela tendência de polimerização das unidades monômeras de $\mathrm{Si}(\mathrm{OH})_{4}$ em excesso, com formação de sílica coloidal ou amorfa que, de acordo com Oliveira (1984), pode impedir a saída do P ou, ainda, ocasionar adsorção do P no próprio polímero de sílica. Este fato, porém, não ocorreu no presente estudo, pois foi justamente nas maiores doses utilizadas (200 e $250 \mathrm{mg} \mathrm{dm}^{-3}$ ) que foi verificado aumento de $\mathrm{P}$ no solo.

$\mathrm{O}$ uso do radoisótopo ${ }^{32} \mathrm{P}$ permitiu determinar na planta a quantidade do $\mathrm{P}$ proveniente do fertilizante (Pppf), e o aproveitamento do fertilizante (AP), pela planta (MURAOKA, 1991). Os dados do Pppf, independente da fonte de Si utilizada (wollastonita ou filossilicato), não se ajustaram em regressões em função das doses de Si aplicadas. Ao avaliar o Pppf dentro de cada uma das fontes em função das doses aplicadas através do teste de médias, a dose 150 $\mathrm{mg} \mathrm{dm}{ }^{-3}$ de Si fornecido via wollastonita apresentou o maior valor de Pppf,. Nas plantas submetidas à aplicação do filossilicato não foi verificada diferença significativa entre as dose para o Pppf. Na comparação entre as fontes silicatadas, nas doses intermediarias de 100 a 200 $\mathrm{mg} \mathrm{dm}{ }^{-3}$, verificou-se que as plantas submetidas à aplicação de Si não diferiram entre si quando avaliados o P proveniente do SFT, sendo que as doses 50 e $250 \mathrm{mg} \mathrm{dm}^{-3}$ de filossilicato promoveram maior valor de Pppf (Tabela 8). 
Tabela 8 - Teor de fósforo $(\mathrm{P})$ na planta proveniente do fertilizante $(\mathrm{Pppf})\left(\mathrm{mg}\right.$ vaso $\left.^{-1}\right) \mathrm{em}$ funcao de fontes e doses de Si.

\begin{tabular}{ccccccc}
\hline & \multicolumn{7}{c}{ Doses de $\mathrm{Si}\left(\mathrm{mg} \mathrm{dm}^{-3}\right)$} \\
Fontes de Si & 0 & 50 & 100 & 150 & 200 & 250 \\
& & & \multicolumn{7}{c}{ Pppf $\left(\mathrm{mg} \mathrm{vaso}^{-1}\right)$} \\
Wollastonita & $1,97 \mathrm{bB}$ & $2,11 \mathrm{bB}$ & $2,23 \mathrm{bA}$ & $2,45 \mathrm{aA}$ & $2,08 \mathrm{bA}$ & $1,39 \mathrm{bB}$ \\
Filossilicato & $2,55 \mathrm{aA}$ & $3,51 \mathrm{aA}$ & $3,05 \mathrm{aA}$ & $3,02 \mathrm{aA}$ & $2,49 \mathrm{aA}$ & $2,62 \mathrm{aA}$ \\
\hline $\mathrm{CV}(\%)$ & 35,98 & & & \\
\hline
\end{tabular}

Letras minúsculas iguais na linha e maiúsculas na coluna não diferem entre si pelo teste de Tukey a 5\%

Os resultados de Pppf (Tabela 8) e P acumulado (Tabela 6) foram semelhantes para a fonte wollastonita, na qual não houve diferença significativa em função das doses de Si. Para o filossilicato, a diferença do $\mathrm{P}$ acumulado foi significativa entre as doses enquanto que o Pppf não variou estatisticamente.

Segundo Ma et al. (1991) ocorre uma substituição parcial do Si pelo P que está presente no solo. Sendo assim, havendo a troca do Si pelo P, o P permanece no solo mais disponível às plantas, justificando a maior quantidade de $\mathrm{P}$ acumulado (Tabela 6).

O comportamento do AP do SFT foi similar ao do Pppf, em que não houve aumento em função das doses de Si aplicadas com a wollastonita e filossilicato (Tabela 9). Ao avaliar o AP do SFT dentro da fonte wollastonita em função das doses de Si aplicadas, observa-se que apenas na dose de $150 \mathrm{mg} \mathrm{dm}^{-3}$ de Si houve aumento no AP, de acordo com teste de médias. Para o filossilicato, como o AP não diferiu entre as doses de $\mathrm{Si}$, este resultado indica que o maior acúmulo de $\mathrm{P}$ na parte aérea da planta (Tabela 6) propiciado pela aplicação de filossilicato, foi absorvido do solo e não do fertilizante.

De modo geral, independente da fonte ou dose utilizada neste estudo, observa-se que os valores do AP foram baixos, pois é conhecido que o aproveitamento do P pelas plantas é próximo de $10 \%$. Franzini (2006), em trabalho com milho, utilizando o SFT marcado com ${ }^{32} \mathrm{P}$ e misturado no solo, obteve aproveitamento do fertilizante fosfatatado próximo de $7 \%$. O resultado do baixo AP encontrado no presente trabalho pode ser explicado pela pouca produção de MSPA (Tabela 5) e, consequentemente, baixo acumulo de P nas plantas. Neste caso, apesar das plantas terem sido coletadas com 50 dias, o desenvolvimento lento refletiu na baixa absorção dos nutrientes deixando o AP próximo de 1,5\% (Tabela 9). 
Tabela 9 - Aproveitamento do fósforo (AP) (\%) via superfosfato triplo (SFT) em função de doses e fontes de silício $(\mathrm{Si})$.

\begin{tabular}{ccccccc}
\hline & \multicolumn{7}{c}{ Doses de Si $\left(\mathrm{mg} \mathrm{dm}^{-3}\right)$} \\
Fontes de Si & 0 & 50 & 100 & 150 & 200 & 250 \\
& $\cdots$ & AP do SFT $(\%)$ & \\
Wollastonita & $1,23 \mathrm{bB}$ & $1,32 \mathrm{bB}$ & $1,40 \mathrm{bA}$ & $1,53 \mathrm{aA}$ & $1,30 \mathrm{bA}$ & $0,87 \mathrm{bB}$ \\
Filossilicato & $1,59 \mathrm{aA}$ & $2,19 \mathrm{aA}$ & $1,91 \mathrm{aA}$ & $1,89 \mathrm{aA}$ & $1,56 \mathrm{aA}$ & $1,64 \mathrm{aA}$ \\
\hline CV $(\%)$ & 34,98 & \multicolumn{7}{c}{} \\
\hline
\end{tabular}

Letras minúsculas iguais na linha e maiúsculas na coluna não diferem entre si pelo teste de Tukey a 5\%

$\mathrm{O}$ acúmulo do Si na planta ajustou significativamente às regressões exponenciais em função das doses aplicadas para as duas fontes de Si avaliadas (Figura 4). O comportamento das curvas de regressão para ambas as fontes foram similares à quantidade de $\mathrm{P}$ acumulado (Figura 2), sugerindo uma possível interação entre os dois elementos.

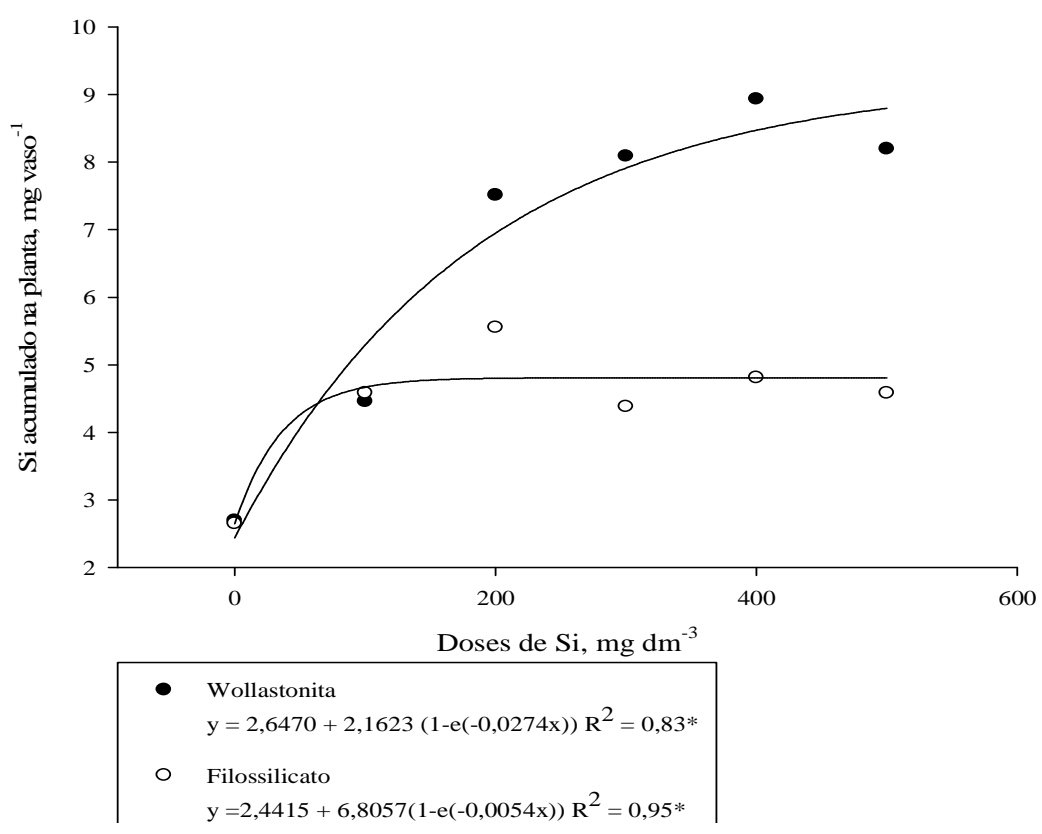

Figura 4 - Efeito de fontes e doses de silício ( $\mathrm{Si}$ ) no $\mathrm{Si}$ acumulado na massa seca da parte aérea de arroz.

Quando realizado o teste de médias, verifica-se que o acúmulo de Si na MSPA aumentou significativamente, sendo que os valores diferiram a partir da dose de $50 \mathrm{mg} \mathrm{dm}^{-3}$ 
independente da fonte utilizada. Em relação à fonte utilizada, as plantas submetidas à aplicação das doses a partir de $100 \mathrm{mg} \mathrm{dm}^{-3}$ de wollastonita obtiveram maiores quantidades de Si acumulado na MSPA quando comparados com a fonte de filossilicato, com exceção das menores doses, 0 e $50 \mathrm{mg} \mathrm{dm}^{-3}$, onde verificou-se que não houve diferenças entre as fontes (Tabela 10).

Sandim (2012) encontraram resultados similares, obtendo incremento na quantidade de Si acumulado na parte aérea do milho, quando as plantas foram submetidas à aplicação tanto da wollastonita quanto com outras duas fontes de Si.

Tabela 10 - Teor de silício ( $\mathrm{Si}$ ) acumulado na massa seca da parte aérea (MSPA) do arroz $\left(\mathrm{mg} \mathrm{vaso}^{-1}\right)$ em função de fontes de doses de Si.

\section{Doses de $\mathrm{Si}\left(\mathrm{mg} \mathrm{dm}^{-3}\right)$}

\begin{tabular}{ccccccc} 
Fontes de Si & 0 & 50 & 100 & 150 & 200 & 250 \\
& $-\ldots$ & Si acumulado $(\mathrm{mg}$ vaso & \\
Wollastonita & $2,69 \mathrm{cA}$ & $4,45 \mathrm{bA}$ & $7,51 \mathrm{aA}$ & $8,09 \mathrm{aA}$ & $8,93 \mathrm{aA}$ & $8,19 \mathrm{aA}$ \\
Filossilicato & $2,65 \mathrm{bA}$ & $4,58 \mathrm{aA}$ & $5,55 \mathrm{aB}$ & $4,38 \mathrm{aB}$ & $4,81 \mathrm{aB}$ & $4,58 \mathrm{aB}$ \\
\hline CV $(\%)$ & 17,01 & & & \\
\hline
\end{tabular}

Letras minúsculas iguais na linha e maiúsculas na coluna não diferem entre si pelo teste de Tukey a 5\%

Os dados encontrados no presente trabalho não corroboram com os resultados obtidos por Pereira et al. (2007) que não observaram diferenças significativas entre a wollastonita e o filossilicato em relação ao controle (sem $\mathrm{Si}$ ), quando analisada a quantidade acumulada deste elemento na parte aérea da planta.

Faria Junior et al. (2009), avaliando a fonte de Si wollastonita, encontraram resultados similares ao do presente estudo, os quais analisaram a quantidade acumulada de Si nas plantas de arroz e, também verificaram que, mesmo as plantas absorvendo maiores quantidades de $\mathrm{Si}$, não houve incremento na matéria seca.

Acréscimo da quantidade de Si acumulado no tecido vegetal de plantas de arroz em função da adubação silicatada foi relatado por Ramos, Korndörfer e Nolla (2008) e Faria Junior et al. (2009), sobretudo em condições tropicais, uma vez que os solos destas regiões são pobres nesse elemento, devido ao avançado grau de intemperismo (BARBOSA FILHO et al., 2001).

$\mathrm{O}$ teor de $\mathrm{Si}$ no solo, avaliados pelo extrator cloreto de cálcio $\left(\mathrm{CaCl}_{2}\right)$, apresentaram comportamento distinto entre as fontes de Si (wollastonita e filossilicato). Quando analisada a wollastonita, o teor de $\mathrm{Si}$ aumentou sendo que os dados se ajustaram significativamente em 
regressão linear. Porém, ao se avaliar o teor de Si presente no solo aplicado como filossilicato, verificou-se que os dados não sofreram nenhuma alteração em relação às doses aplicadas (sem Si) (Figura 5).

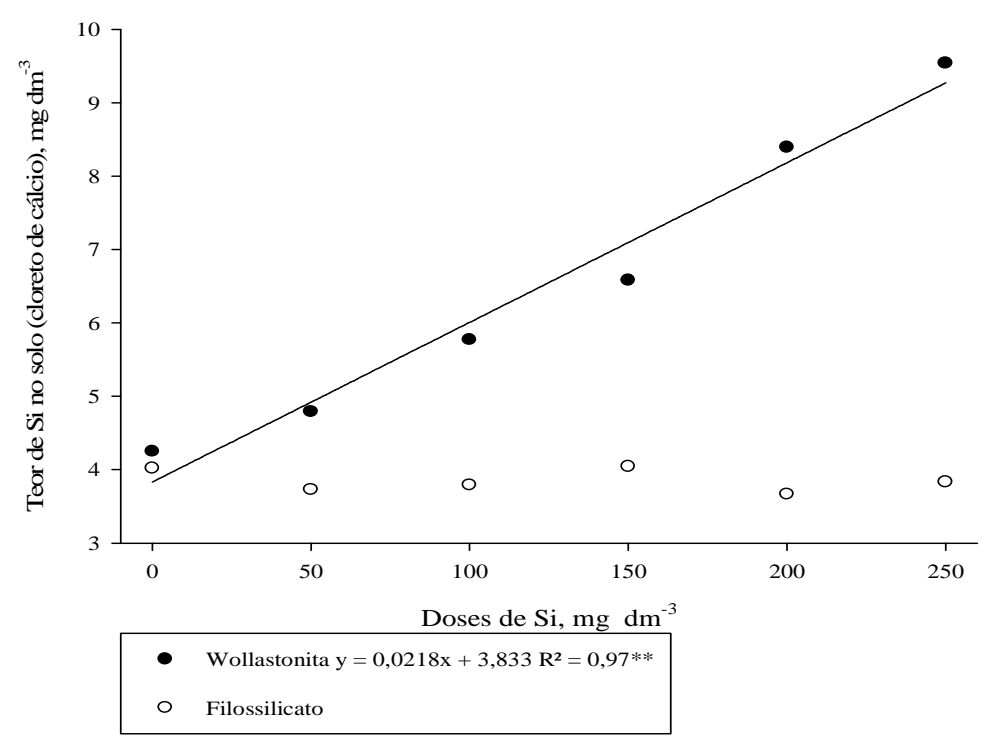

Figura 5 - Efeito de fontes e doses de silício ( $\mathrm{Si}$ ) no teor de Si no solo extraído pelo cloreto de cálcio.

Ao se comparar o teor de $\mathrm{Si}$ no solo utilizando teste de médias a cada fonte (wollastonita e filossilicato), verificou-se que a wollastonita liberou Si no solo, onde os maiores teores foram obtidos com as doses 200 e $250 \mathrm{mg} \mathrm{dm}^{-3}$, enquanto que o tratamento controle foi o menor entre eles (Tabela 11). Este comportamento já era esperado, pois a wollastonita é a fonte padrão em estudos de Si devido ao seu alto grau de pureza, rico em $\mathrm{CaSiO}_{3}$ (PEREIRA et al., 2003).

Tabela 11 - Teor de silício ( $\mathrm{Si})$ no solo pelo extrator cloreto de cálcio $\left(\mathrm{CaCl}_{2}\right)$ em função de fontes e doses de $\mathrm{Si}$.

\begin{tabular}{|c|c|c|c|c|c|c|}
\hline \multirow[b]{2}{*}{ Fontes de Silício } & \multicolumn{6}{|c|}{ Doses de $\mathrm{Si}\left(\mathrm{mg} \mathrm{dm}^{-3}\right)$} \\
\hline & 0 & 50 & 100 & 150 & 200 & 250 \\
\hline & \multicolumn{6}{|c|}{ Teor de Si no solo $\left(\mathrm{mg} \mathrm{dm}^{3}\right)$} \\
\hline Wollastonita & $4,25 \mathrm{dA}$ & $4,79 \mathrm{cA}$ & $5,77 \mathrm{abA}$ & $6,58 \mathrm{bA}$ & 8,39 aA & $9,54 \mathrm{aA}$ \\
\hline Filossilicato & $4,02 \mathrm{aB}$ & $3,73 \mathrm{aB}$ & $3,79 \mathrm{aB}$ & $4,04 \mathrm{aB}$ & $3,66 \mathrm{aB}$ & $3,83 \mathrm{aB}$ \\
\hline $\mathrm{CV}(\%)$ & 9,23 & & & & & \\
\hline
\end{tabular}

Letras minúsculas iguais na linha e maiúsculas na coluna não diferem entre si pelo teste de Tukey a 5\% 
Alterações no teor de Si no solo, em função da aplicação do filossilicato não foram detectadas pelo extrator cloreto de cálcio em nenhuma dose utilizada. Mesmo quando aplicado $250 \mathrm{mg} \mathrm{dm}^{-3}$, o teor obtido não diferenciou do tratamento controle (Tabela 11). Uma justificativa seria a não liberação do Si por parte desta fonte, entretanto como o Si acumulado na planta foi superior em todas as doses utilizadas quando comparado à planta que não recebeu Si via filossilicato (Tabela 10), esta hipótese está descartada. Uma explicação para a ausência do aumento do teor de Si em função das doses de filossilicato é a baixa eficiência do cloreto de cálcio em extrair o Si proveniente do filossilicato. Outra possível e mais provável explicação, seria a liberação mais lenta ou gradual do Si por parte desta fonte, fazendo com que o pouco que foi liberado no solo, foi rapidamente absorvido pela planta.

O extrator cloreto de cálcio apresentou alta correlação com o Si acumulado na planta, quando aplicada a fonte padrão (wollastonita) ou diversas escórias de siderurgia (SANDIM, 2012; CAMARGO et al., 2007; BARBOSA et al., 2008; KORNDÖRFER; LEPSCH, 2001).

Os resultados encontrados corroboram com Pereira et al. (2007) que trabalharam com diversas fontes silicatadas, no qual o teor de Si no solo não foi detectado por nenhum extrator quando aplicado como filossilicato. Segundo esses autores, este fato ocorreu por ser proveniente de matéria prima diferente das escórias de siderurgia.

Ao utilizar o ácido acético como extrator, verificou-se que o comportamento dos resultados referentes ao teor de Si no solo se comportou de forma similar ao extrator cloreto de cálcio. A fonte wollastonita promoveu aumento no teor de $\mathrm{Si}$ no solo quando este foi extraído com acido acético, a qual se ajustou a uma regressão linear em função das doses utilizadas. Conforme já discutido acima, este resultado era esperado, pois esta é uma fonte padrão para estudos com silício. Já quando utilizada a fonte proveniente de filossilicatos, novamente, não houve efeito (Figura 6). 


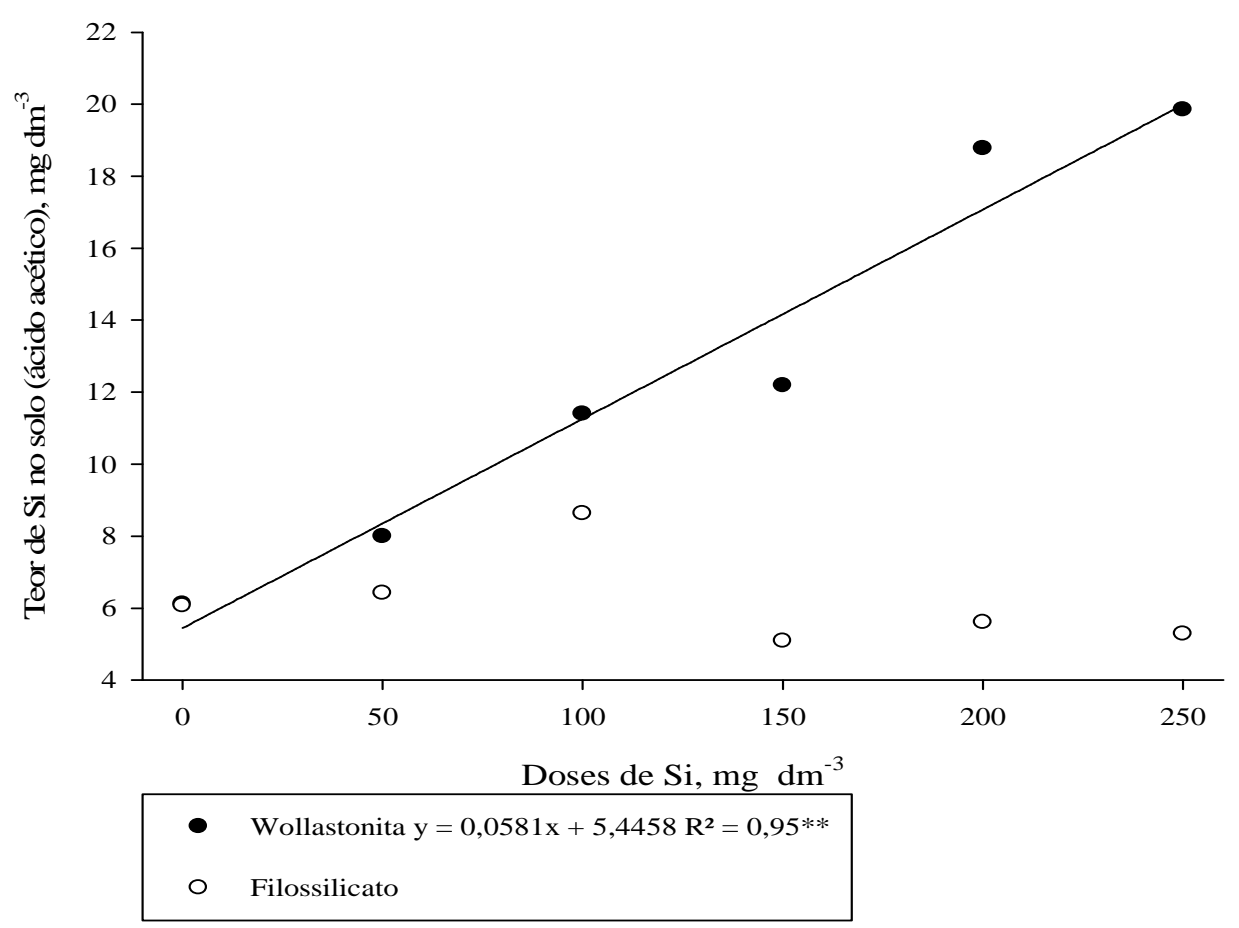

Figura 6 - Efeito de fontes e doses de silício (Si) no teor de Si no solo extraído pelo ácido acético.

Comparando as doses de cada uma das fontes de Si através do teste de médias, verificou-se que o tratamento sem $\mathrm{Si}$ obteve a menor média enquanto que as doses maiores da wollastonita (200 e $250 \mathrm{mg} \mathrm{dm}^{-3}$ ) incrementaram o teor de Si no solo. Já a fonte de filossilicato, novamente, não diferenciou significativamente o teor liberado no solo em nenhuma das doses (Tabela 12), corroborando com a hipótese citada acima, de que houve pouco Si liberado naquele instante, fazendo com que já fosse absorvido pela planta, não deixando residual para ser detectado no solo. Em trabalho comparando a wollastonita à outra fonte comercial, de matéria prima também diferente, Ramos, Korndörfer e Nolla (2008) verificaram que apenas a wollastonita foi detectada pelos extratores cloreto de cálcio e acido acético, enquanto que a outra fonte silicatada não diferiu da testemunha. 
Tabela 12 - Teor de silício ( $\mathrm{Si}$ ) no solo extraído pelo ácido acético em função de fontes e doses de $\mathrm{Si}$.

\begin{tabular}{ccccccc}
\hline & \multicolumn{7}{c}{ Doses de Si $\left(\mathrm{mg} \mathrm{dm}^{-3}\right)$} \\
Fontes de Si & 0 & 50 & 100 & 150 & 200 & 250 \\
& $\cdots$ & \multicolumn{7}{c}{ Teor de Si no solo $\left.(\mathrm{mg} \mathrm{dm})^{-3}\right)$} \\
Wollastonita & $6,12 \mathrm{dA}$ & $7,99 \mathrm{cdA}$ & $11,39 \mathrm{cbA}$ & $12,18 \mathrm{bA}$ & $18,76 \mathrm{aA}$ & $19,85 \mathrm{aA}$ \\
Filossilicato & $6,07 \mathrm{aA}$ & $6,41 \mathrm{aB}$ & $8,62 \mathrm{aB}$ & $5,08 \mathrm{aB}$ & $5,60 \mathrm{aB}$ & $5,28 \mathrm{aB}$ \\
\hline $\mathrm{CV}(\%)$ & 12,93 & & & \\
\hline
\end{tabular}

Letras minúsculas iguais na linha e maiúsculas na coluna não diferem entre si pelo teste de Tukey a 5\%

Os menores teores de $\mathrm{Si}$ encontrados nos tratamentos que não receberam adubação silicatada, para ambos os extratores utilizados, são consequência do seu avançado grau de intemperismo e lixiviação, assim como dos elevados teores de óxidos de $\mathrm{Fe}$ e Al, que são os principais responsáveis pela adsorção do Si da solução do solo (TOKURA et al. 2007).

A extração de Si pelo ácido acético revelou valores superiores em relação ao extrator cloreto de cálcio para todas as doses (Figura 7). Provavelmente, esse processo ocorreu porque este extrator é capaz de extrair Si não disponível para as plantas, tais como formas polimerizadas ou mesmo Si presente na fase sólida do solo (argilominerais) superestimando os valores de silício em solução (QUEIROZ, 2003; BRAGA, 2004; VIDAL, 2005).

Esse resultado pode ser observado em todas as doses, concordando com os obtidos por Pereira et al. (2004) e Braga (2004) que, trabalhando com doses crescentes de sílica gel nas culturas de arroz e sorgo, também observaram incremento nos teores de Si no solo extraído com ácido acético em comparação ao cloreto de cálcio. 


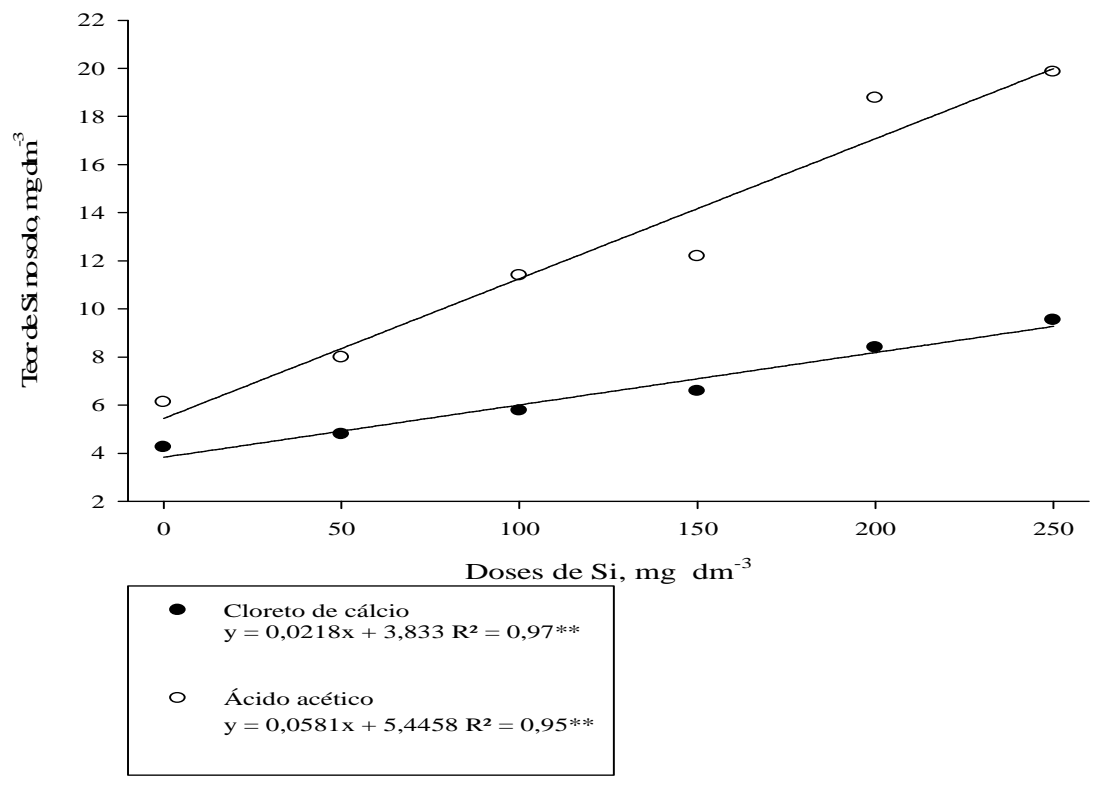

Figura 7 - Efeito de doses de wollastonita no teor de Si no solo extraído pelo cloreto de cálcio e ácido acético.

\subsubsection{Experimento 2: Formas de aplicação de silício e fósforo no aproveitamento do superfosfato triplo pelo arroz}

Os resultados obtidos da MSPA demonstraram que não houve efeito significativo independente da fonte ou forma de aplicação do Si no solo (Tabela 13).

Tabela 13 - Massa seca de parte área (MSPA) do arroz $\left(\mathrm{g} \mathrm{vaso}^{-1}\right)$ em função das formas de aplicação do silício ( $\mathrm{Si}$ ), em área total e localizada, para as fontes wollastonita e filossilicato.

Fontes de $\mathrm{Si}$

$$
\text { Formas de aplicação }
$$

Área total Localizado

$\operatorname{MSPA}\left(\mathrm{g}\right.$ vaso $\left.^{-1}\right)$
Controle
$2,39 \mathrm{aA}$
$2,85 \mathrm{aA}$
Wollastonita
$2,54 \mathrm{aA}$
2,29 aA
Filossilicato
2,18 aA
$1,96 \mathrm{aA}$

\section{CV (\%) $\quad 17,34$}

Letras minúsculas iguais na linha e maiúsculas na coluna não diferem entre si pelo teste de Tukey a 5\% 
Este resultado corrobora com os encontrados por Barbosa et al. (2008), que em trabalho de campo com sorgo, verificaram que a presença de Si e a forma de aplicação do silicato de cálcio (no sulco ou em área total), não influenciaram na massa seca da parte aérea da planta. Orioli Júnior et al. (2008) verificaram que os modos de aplicação de silício (apenas a lanço ou a lanço seguido de escarificação) não interferiram na produtividade da cultura do trigo.

Artigiani et al. (2014), trabalhando com plantas de arroz e com Si na dose de $100 \mathrm{~kg}$ $\mathrm{ha}^{-1}$, concluíram que a aplicação de Si no sulco de semeadura não proporcionou incremento na produtividade de grãos de arroz

A reposta das plantas neste experimento foi similar ao encontrado no primeiro experimento, pois a forma de aplicação foi em área total, e a dose aplicada a correspondente do experimento 1, também não apresentou diferença quando aplicada a fonte wollastonita. Entretanto, como a MSPA do tratamento controle deste experimento 2 foi maior do que o as do tratamento controle do experimento 1, pode ter sido o motivo para que não houvesse diferença para a fonte de filossilicatos, diferentemente do ocorrido no experimento 1.

Os dados sobre o P acumulado nas plantas de arroz demonstraram, de maneira análoga ao que foi obtido para a MSPA (Tabela 13), que não houve diferença independente fonte ou forma de aplicação do Si no solo (Tabela 14).

Tabela 14 - Fósforo (P) acumulado na planta $\left(\mathrm{mg} \mathrm{vaso}^{-1}\right)$ em arroz em função da forma de aplicação, área total e localizada, para as fontes de silício ( $\mathrm{Si}$ ) wollastonita e filossilicato.

\begin{tabular}{clc}
\hline Fontes de Si & $\begin{array}{l}\text { Formas de aplicação } \\
\text { Área total }\end{array}$ & Localizado \\
\hline Controle & P acumulado $\left(\mathrm{mg} \mathrm{vaso}^{-1}\right)$ & \\
Wollastonita & $4,43 \mathrm{aA}$ & $4,45 \mathrm{aA}$ \\
Filossilicato & $4,57 \mathrm{aA}$ & $4,21 \mathrm{aA}$ \\
\hline
\end{tabular}

$\mathrm{CV}(\%) \quad 16,99$

Letras minúsculas iguais na linha e maiúsculas na coluna não diferem entre si pelo teste de Tukey a 5\%

Silva e Bohnen (2001) avaliaram o acúmulo de nutrientes pelo arroz, em solução nutritiva, variou com a ausência ou presença de Si. Os autores concluíram que com a adição do Si, não houve alteração significativa no $\mathrm{P}$ acumulado na parte aérea das plantas. 
Vidal e Prado (2011), trabalhando com plantas de arroz submetidas a aplicação de calcário e silício via escorias de siderurgia, observaram em doses bem elevadas chegando até 10 toneladas por hectare, incremento significativo no $\mathrm{P}$ acumulado pelas plantas.

Ao se analisar o $\mathrm{P}$ acumulado na planta deste experimento, com o do anterior, no qual se variou as doses de $\mathrm{Si}$, percebeu-se que as plantas submetidas à aplicação de wollastonita não obtiveram diferenças. As plantas do tratamento controle, do presente experimento, absorveram mais $\mathrm{P}$ em relação o controle do primeiro experimento, fazendo com que, neste estudo, não houvesse alteração significativa para a fonte de filossilicatos.

$\mathrm{O}$ teor de $\mathrm{P}$ no solo, em relação às fontes e formas de aplicação do $\mathrm{Si}$, apresentou comportamento similar não havendo nenhuma diferente significativa entre eles (Tabela 15).

Em relação ao experimento anterior, os dados referentes ao teor de $\mathrm{P}$ no solo, a fonte de filossilicatos se apresentaram de maneira análoga a este. Já para o P no solo aplicado via wollastonita apresentou incremento no primeiro estudo (Tabela 7).

Tabela 15 - Fósforo $(\mathrm{P})$ no solo $\left(\mathrm{mg} \mathrm{dm}^{-3}\right)$ em função das formas de aplicação, área total e localizada, das fontes wollastonita e filossilicato.

\begin{tabular}{ccc}
\hline Fontes de Si & $\begin{array}{l}\text { Formas de aplicação } \\
\text { Área total }\end{array}$ & Localizado \\
\hline Controle & Teor de P no solo $\left(\mathrm{mg} \mathrm{dm}^{-3}\right)$ & $38,36 \mathrm{aA}$ \\
Wollastonita & $38,63 \mathrm{aA}$ & $44,21 \mathrm{aA}$ \\
Filossilicato & $40,61 \mathrm{aA}$ & $45,62 \mathrm{aA}$ \\
\hline $\mathrm{CV}(\%)$ & $36,62 \mathrm{aA}$ & \\
\hline
\end{tabular}

Letras minúsculas iguais na linha e maiúsculas na coluna não diferem entre si pelo teste de Tukey a 5\%

Os valores de Pppf foram similares tanto para o tratamento controle (que não recebeu aplicação de $\mathrm{Si}$ ) quanto ao tratamento com $\mathrm{Si}$, onde as fontes de $\mathrm{Si}$ foram aplicadas na forma localizada em sulco. Porém, quando o $\mathrm{Si}$ foi aplicado misturado ao solo, houve maior absorção do $\mathrm{P}$ proveniente do SFT pelas plantas, que foram submetidas à aplicação do Si, independente da fonte (wollastonita ou filossilicato) em relação ao tratamento controle (Tabela 16). 
Tabela 16 - Teor de fósforo na planta proveniente do fertilizante (Pppf) $\left(\mathrm{mg} \mathrm{vaso}^{-1}\right)$ em função de formas de aplicação, área total e localizada, das fontes wollastonita e filossilicato.

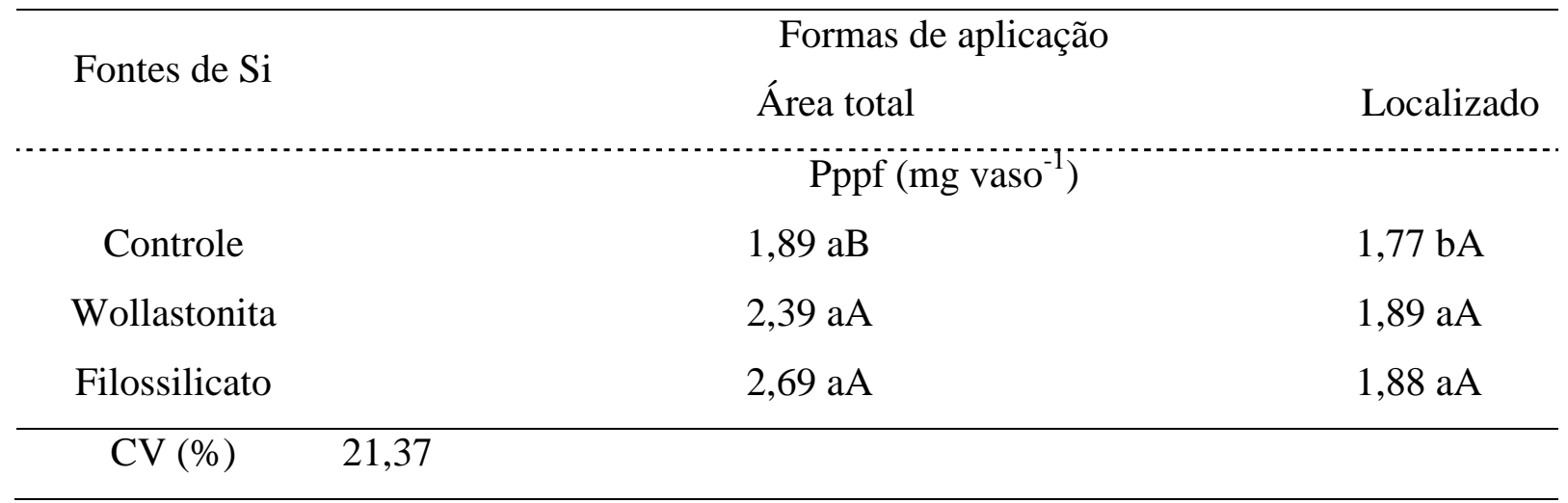

Letras minúsculas iguais na linha e maiúsculas na coluna não diferem entre si pelo teste de Tukey a 5\%

Os dados obtidos do AP do SFT se comportaram de maneira semelhante ao Pppf, no qual quando o Si foi aplicado de forma localizada, o aproveitamento do fertilizante fosfatado não diferiu em relação ao tratamento controle. Se aplicado em área total, o AP foi superior em relação ao tratamento controle, independente da dose de Si utilizada (Tabela 17).

Tabela 17 - Aproveitamento do fósforo (AP) do superfosfato triplo em função de formas de aplicação, área total e localizada, das fontes wollastonita e filossilicato.

Fontes de Si Formas de aplicação

Área total Localizado

\begin{tabular}{|c|c|c|}
\hline \multicolumn{3}{|c|}{$\mathrm{AP}(\%)$} \\
\hline Controle & $1,24 \mathrm{aB}$ & $1,10 \mathrm{bA}$ \\
\hline Wollastonita & $1,50 \mathrm{aA}$ & $1,18 \mathrm{aA}$ \\
\hline Filossilicato & $1,68 \mathrm{aA}$ & $1,17 \mathrm{aA}$ \\
\hline
\end{tabular}

Letras minúsculas iguais na linha e maiúsculas na coluna não diferem entre si pelo teste de Tukey a 5\%

Neste experimento, o AP também pode ser considerado baixo se comparado com dados conhecidos na literatura, assim como ocorreu no experimento 1. Conforme já discutido anteriormente, a baixa porcentagem do aproveitamento do $\mathrm{P}$ pode ser reflexo do baixo crescimento da MSPA e consequente baixa exigência de nutrientes.

Ao comparar formas de aplicação do SFT, Franzini (2006) constatou que quando o fertilizante foi aplicado de forma localizada, o aproveitamento foi superior do que em área total. Este comportamento não foi observado no presente estudo para o tratamento controle que recebeu apenas dose de $\mathrm{P}$ (sem Si) (Tabela 17). 
O acúmulo de Si nas plantas de arroz, submetidas à aplicação de fontes e formas de Si distintas não diferiram independente do tratamento (Tabela 18).

Tabela 18 - Silicio (Si) acumulado ( $\mathrm{mg} \mathrm{vaso}^{-1}$ ) em plantas de arroz em função da forma de aplicação, área total e localizada, das fontes de silício $(\mathrm{Si})$ wollastonita e filossilicato.

\begin{tabular}{clc}
\hline Fontes de $\mathrm{Si}$ & $\begin{array}{l}\text { Formas de aplicação } \\
\text { Área total }\end{array}$ & Localizado \\
\hline Controle & Si acumulado $\left(\mathrm{mg}\right.$ vaso $\left.{ }^{2}\right)$ & $1,49 \mathrm{aA}$ \\
Wollastonita & $1,47 \mathrm{aA}$ & $1,43 \mathrm{aA}$ \\
Filossilicato & $1,54 \mathrm{aA}$ & $1,33 \mathrm{aA}$ \\
\hline $\mathrm{CV}(\%)$ & $1,49 \mathrm{aA}$ & \\
\hline
\end{tabular}

Letras minúsculas iguais na linha e maiúsculas na coluna não diferem entre si pelo teste de Tukey a 5\%

Os dados encontrados neste experimento corroboram com os encontrados por Artigiani et al. (2014) que trabalharam com Si aplicado no sulco de plantio e verificaram que esta forma de aplicação não altera o teor do elemento no solo. Barbosa et al. (2008), em trabalhos com formas de aplicação de Si verificaram que ambos modos de aplicação (sulco e área total) incrementaram de forma significativa o teor e acumulo desse elemento pelas plantas de sorgo. A ausência de diferença entre as formas de aplicação de Si observadas neste experimento pode ser explicada pelo fato de o experimento ter sido conduzido em vasos, onde os nutrientes permaneceram próximo as raizes, independente da forma aplicada. Embora esperava-se que esta dose $\left(125 \mathrm{mg} \mathrm{dm}^{-3}\right)$ fizesse com que ambas as fontes promovessem maior absorção de Si pelas plantas, principalmente na forma aplicada em área total, a mesma do experimento anterior (no qual as doses variaram entre 0 e $250 \mathrm{mg} \mathrm{dm}^{-3}$ ), e que foi constatado tal efeito com doses similares a utilizadas neste ensaio.

Os teores de $\mathrm{Si}$ no solo apresentou o mesmo comportamento observado no experimento anterior (no qual se variaram as doses de $\mathrm{Si}$ ). Os dois extratores, cloreto de cálcio e acido acético, detectaram de forma eficiente apenas a fonte wollastonita. No presente estudo, o extrator ácido acético obteve maiores teores de Si no solo (Tabelas 19 e 20). 
Tabela 19 - Teor de silício $(\mathrm{Si})\left(\mathrm{mg} \mathrm{dm}^{-3}\right)$ extraído pelo cloreto de cálcio $\left(\mathrm{CaCl}_{2}\right)$ em função das formas de aplicação, área total e localizada, das fontes wollastonita e filossilicato.

\begin{tabular}{|c|c|c|}
\hline \multirow{2}{*}{ Fontes de $\mathrm{Si}$} & \multicolumn{2}{|c|}{ Formas de aplicação } \\
\hline & Área total & Localizado \\
\hline \multicolumn{3}{|c|}{ Teor de Si no solo $\left(\mathrm{mg} \mathrm{dm}^{-3}\right)$} \\
\hline Controle & $3,56 \mathrm{aB}$ & $3,71 \mathrm{aB}$ \\
\hline Wollastonita & $6,81 \mathrm{aA}$ & $8,62 \mathrm{aA}$ \\
\hline Filossilicato & $5,00 \mathrm{aB}$ & $4,83 \mathrm{aB}$ \\
\hline $\mathrm{CV}(\%)$ & \multicolumn{2}{|l|}{21,58} \\
\hline \multicolumn{3}{|c|}{ Letras minúsculas iguais na linha e maiúsculas na coluna não diferem entre si pelo teste de Tukey a 5\% } \\
\hline \multicolumn{3}{|c|}{$\begin{array}{c}\text { Tabela } 20 \text { - Teor de silício }(\mathrm{Si})\left(\mathrm{mg} \mathrm{dm}^{-3}\right) \text { extraído pelo ácido acético em função das formas } \\
\text { de aplicação, área total e localizada, das fontes wollastonita e filossilicato. }\end{array}$} \\
\hline \multirow{3}{*}{ Fontes de $\mathrm{Si}$} & \multicolumn{2}{|c|}{ Formas de aplicação } \\
\hline & Área total & Localizado \\
\hline & \multicolumn{2}{|c|}{ Teor de Si no solo $\left(\mathrm{mg} \mathrm{dm}^{3}\right)$} \\
\hline Controle & $4,99 \mathrm{aB}$ & $4,81 \mathrm{aB}$ \\
\hline Wollastonita & $11,29 \mathrm{aA}$ & $10,12 \mathrm{aA}$ \\
\hline Filossilicato & $5,89 \mathrm{aB}$ & $5,01 \mathrm{aB}$ \\
\hline
\end{tabular}

Letras minúsculas iguais na linha e maiúsculas na coluna não diferem entre si pelo teste de Tukey a 5\%

De acordo com Hallmarck (1965), em virtude do pH do extrator ácido acético ser próximo de 2, explica o fato deste extrair mais Si do que o cloreto de cálcio. Pois esta é uma condição necessária para que haja a formação do complexo silico-molíbdico na determinação do silício pelo método do azul de molibdênio.

\subsubsection{Experimento 3: Incubação do solo após a aplicação de fósforo e doses de silício}

O teor de Si no solo determinado pelo extrator cloreto de cálcio modificou em função da aplicação da fonte padrão (wollastonita) o qual se ajustou à regressão quadrática em função das doses (Figura 8). Já quando aplicada a fonte filossilicato, verificou-se que os teores de $\mathrm{Si}$ aumentaram em função da dose e ajustaram-se em uma regressão linear (Figura 9). 


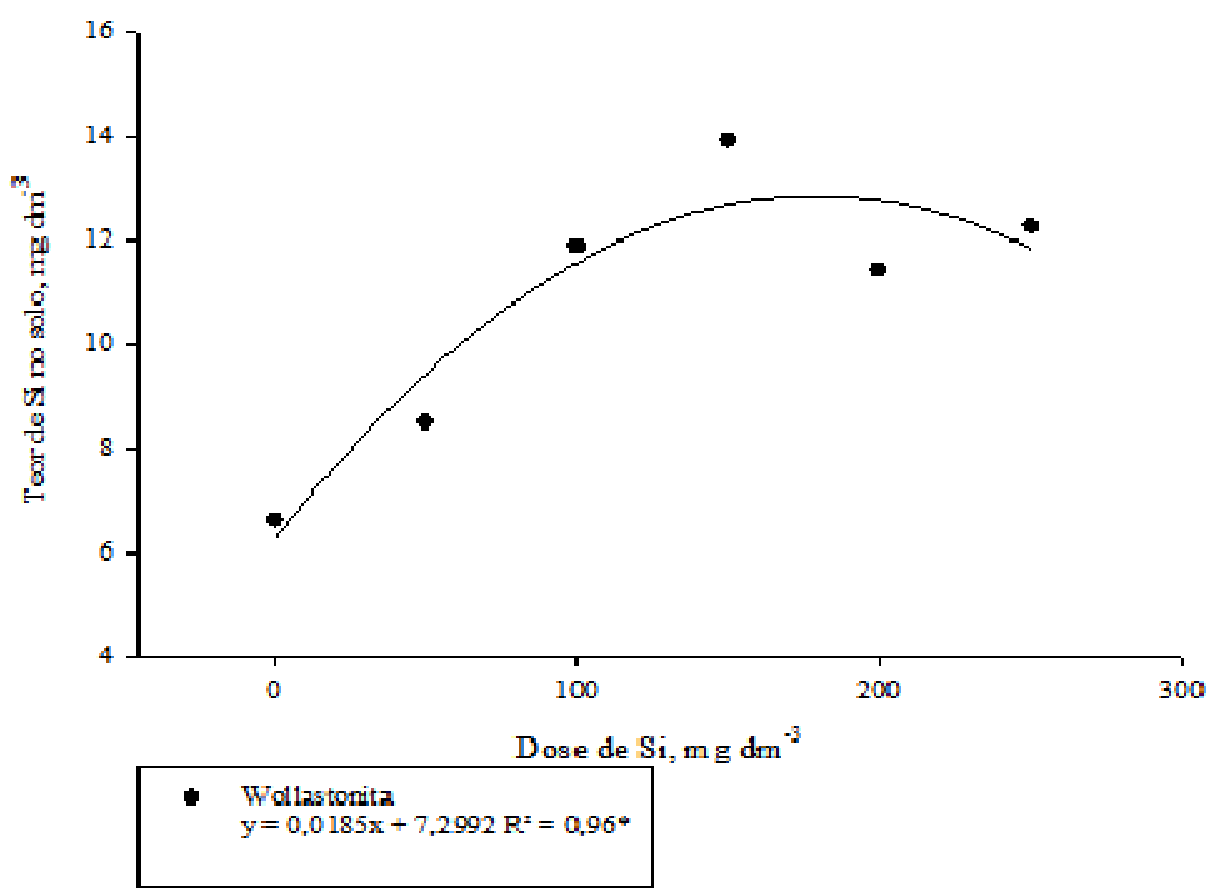

Figura 8 - Teor de silício (Si) extraído por cloreto de cálcio $\left(\mathrm{CaCl}_{2}\right)$ em função da aplicação de doses de wollastonita.

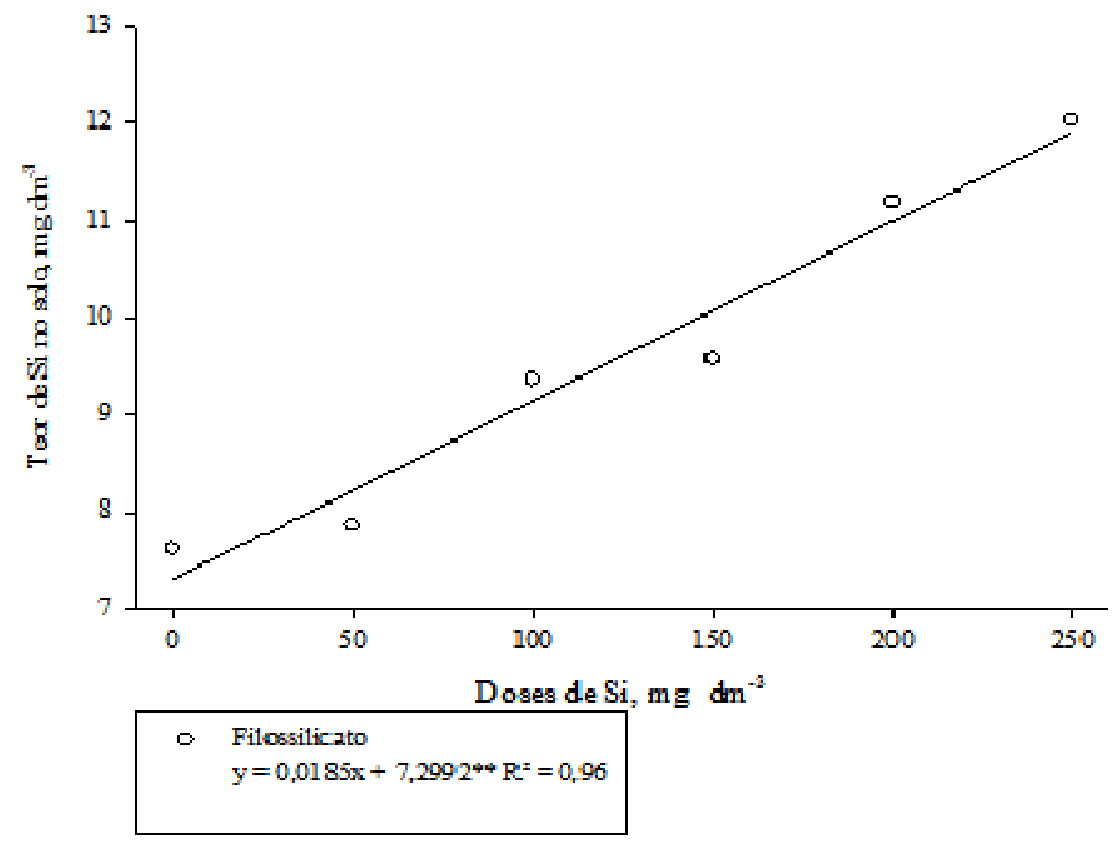

Figura 9 - Teor de silício ( $\mathrm{Si}$ ) no solo extraído por cloreto de cálcio $\left(\mathrm{CaCl}_{2}\right)$ em função da aplicação de doses de filossilicato. 
De acordo com o teste de médias, observou-se que o teor de Si no solo no tratamento com aplicação da fonte wollastonita apresentou aumento significativo a partir da dose referente a $100 \mathrm{mg} \mathrm{dm}^{-3}$, enquanto que para a fonte filossilicato, o maiores teores foram alcançados apenas nas doses de 200 e $250 \mathrm{mg} \mathrm{dm}^{-3}$. Este fato sugere que o filossilicato libera o Si no solo de forma menos intensa que a wollastonita, corroborando com os dados encontrados para o teor desse elemento no solo no experimento 1 e corroborando com uma das hipóteses sugeridas do primeiro experimento, no qual se variaram as doses de $\mathrm{Si}$ aplicadas, de que em virtude desta liberação mais gradual, as plantas absorveram o pouco Si que foi liberado, fazendo com que não houvesse alteração deste elemento no solo (Tabela 21). A tendência é de que uma fonte que apresente liberação do Si de forma mais lenta, apresente efeito residual mais longo no solo (PEREIRA et al., 2003).

Tabela 21 - Teor de silício ( $\mathrm{Si})$ no solo $\left(\mathrm{mg} \mathrm{dm}^{-3}\right)$ extraído pelo cloreto de cálcio $\left(\mathrm{CaCl}_{2}\right)$ para doses das fontes de Si wollastonita e filossilicato.

Fontes de $\mathrm{Si}$ Doses de $\mathrm{Si}\left(\mathrm{mg} \mathrm{dm}^{-3}\right)$

$\begin{array}{llllll}0 & 50 & 100 & 150 & 200 & 250\end{array}$

\begin{tabular}{ccccccc} 
& \multicolumn{7}{c}{ Teor de Si no solo $\left(\mathrm{mg} . \mathrm{dm}^{3}\right)$} \\
Wollastonita & $6,61 \mathrm{bA}$ & $8,49 \mathrm{bA}$ & $11,86 \mathrm{aA}$ & $13,90 \mathrm{aA}$ & $11,40 \mathrm{aA}$ & $12,24 \mathrm{aA}$ \\
Filossilicato & $7,61 \mathrm{bA}$ & $7,86 \mathrm{bA}$ & $9,36 \mathrm{abB}$ & $9,57 \mathrm{abB}$ & $11,20 \mathrm{aA}$ & $12,03 \mathrm{aA}$ \\
\hline $\mathrm{CV}(\%)$ & 11,04 & \multicolumn{7}{c}{$\%$}
\end{tabular}

Letras minúsculas iguais na linha e maiúsculas na coluna não diferem entre si pelo teste de Tukey a 5\%

Ao analisar o teor de Si no solo, extraído por cloreto de cálcio, para cada uma das doses estudadas (200 e $250 \mathrm{mg} \mathrm{dm}^{-3}$ ) em função do tempo, que variou de 0 a 90 dias, verificou-se que para a fonte wollastonita, as doses de 200 e $250 \mathrm{mg} \mathrm{dm}^{-3}$ se ajustaram em uma regressão cúbica, alcançando um ponto máximo de teor de Si de 12,65 de 13,70 $\mathrm{mg} \mathrm{dm}^{-3}$ para as doses de 200 e $250 \mathrm{mg} \mathrm{dm}^{-3}$ respectivamente aplicadas no solo (Figura 10). 


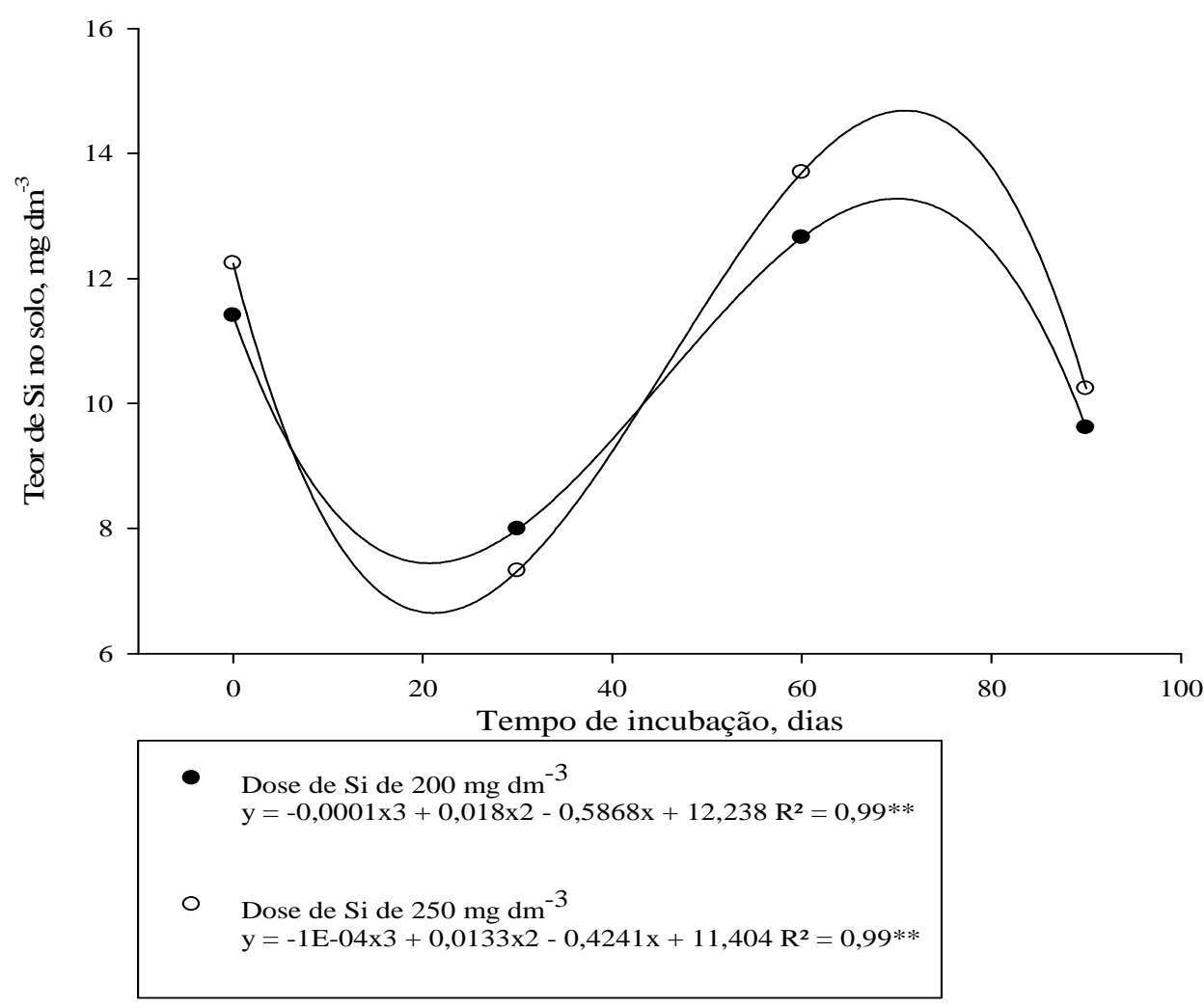

Figura 10 - Teor de silício ( $\mathrm{Si})$ no solo $\left(\mathrm{mg} \mathrm{dm}^{-3}\right)$ extraído por cloreto de cálcio pela aplicação de 200 e $250 \mathrm{mg} \mathrm{dm}^{-3}$ de Si via wollastonita em função dos dias de incubação.

Para a fonte de Si filossilicato, todas as doses, com exceção do tratamento controle, se ajustaram em regressões cúbicas, sugerindo que com o passar do tempo, ocorreu aumento do teor de Si liberado por esta fonte em relação ao tempo 0. Independentemente da dose utilizada, os maiores teores de Si no solo, foram obtidos entre 60 e 70 dias após a aplicação da fonte no solo (Figura 11). 


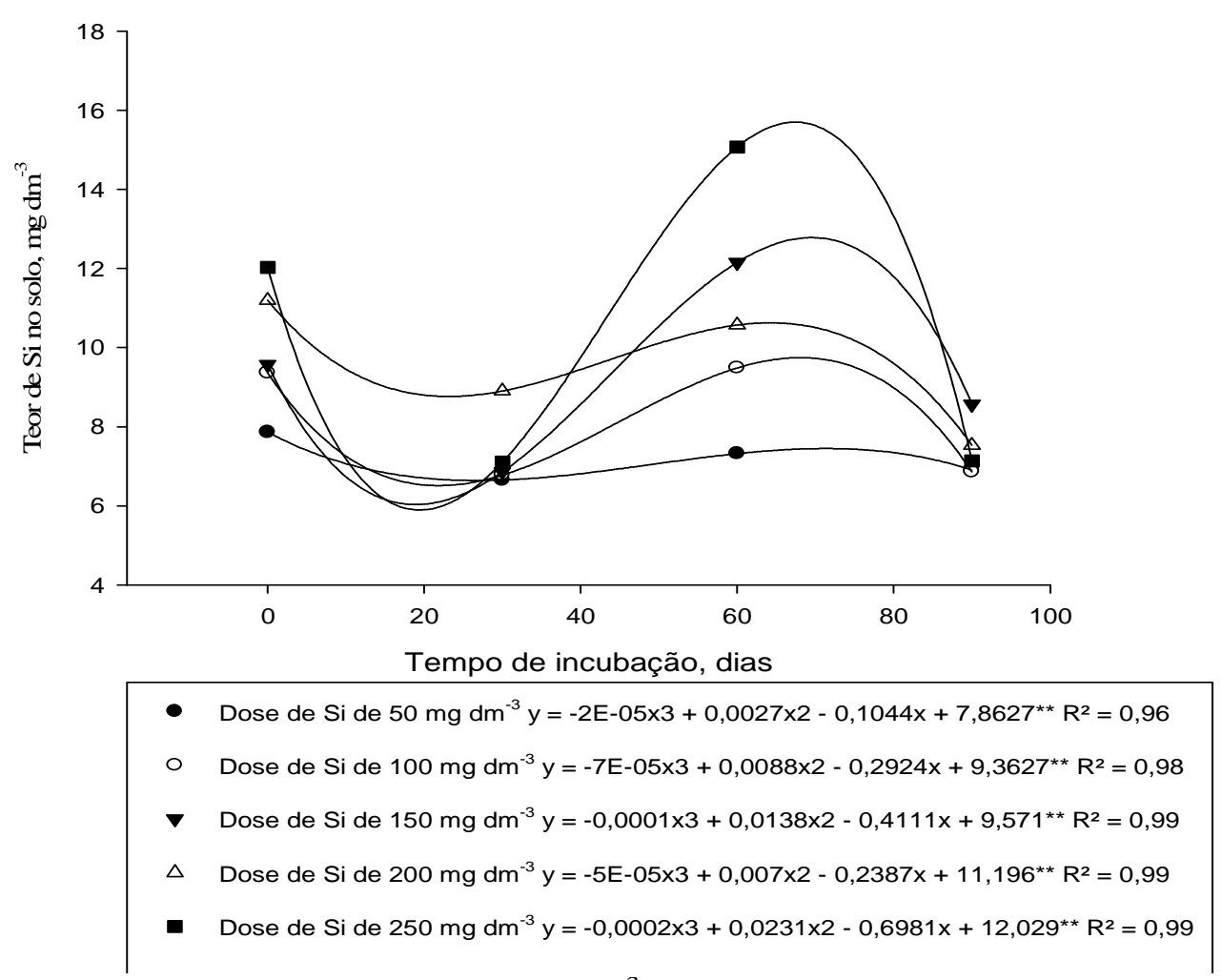

Figura 11 - Teor de silício ( $\mathrm{Si})$ no solo $\left(\mathrm{mg} \mathrm{dm}^{-3}\right)$ extraído por cloreto de cálcio pela aplicação de 50,100,150, 200 e $250 \mathrm{mg} \mathrm{dm}^{-3}$ de Si via filossilicato em função dos dias de incubação.

Os dados encontrados neste experimento para a wollastonita, nas doses mais altas, e para o filossilicato independente da dose aplicada, estão de acordo com Gomes et al. (2011), que avaliaram a disponibilidade de silício para a cultura do arroz, aplicando $300 \mathrm{mg} \mathrm{dm}^{-3} \mathrm{de}$ wollastonita e de escória de siderurgia, no qual obtiveram os teores máximos em torno de 50 a 70 dias.

Quando se utilizou o extrator ácido acético, para ambas as fontes utilizadas, os teores de Si no solo modificaram em função das doses estudadas no tempo 0 (logo após a aplicação), ajustando-se a regressão linear (Figura 12). O extrator ácido acético promoveu comportamento diferente do que ocorreu com o Si avaliado com o extrator cloreto de cálcio na qual houve ajuste quadrático quando aplicada a wollastonita (Figura 8). 


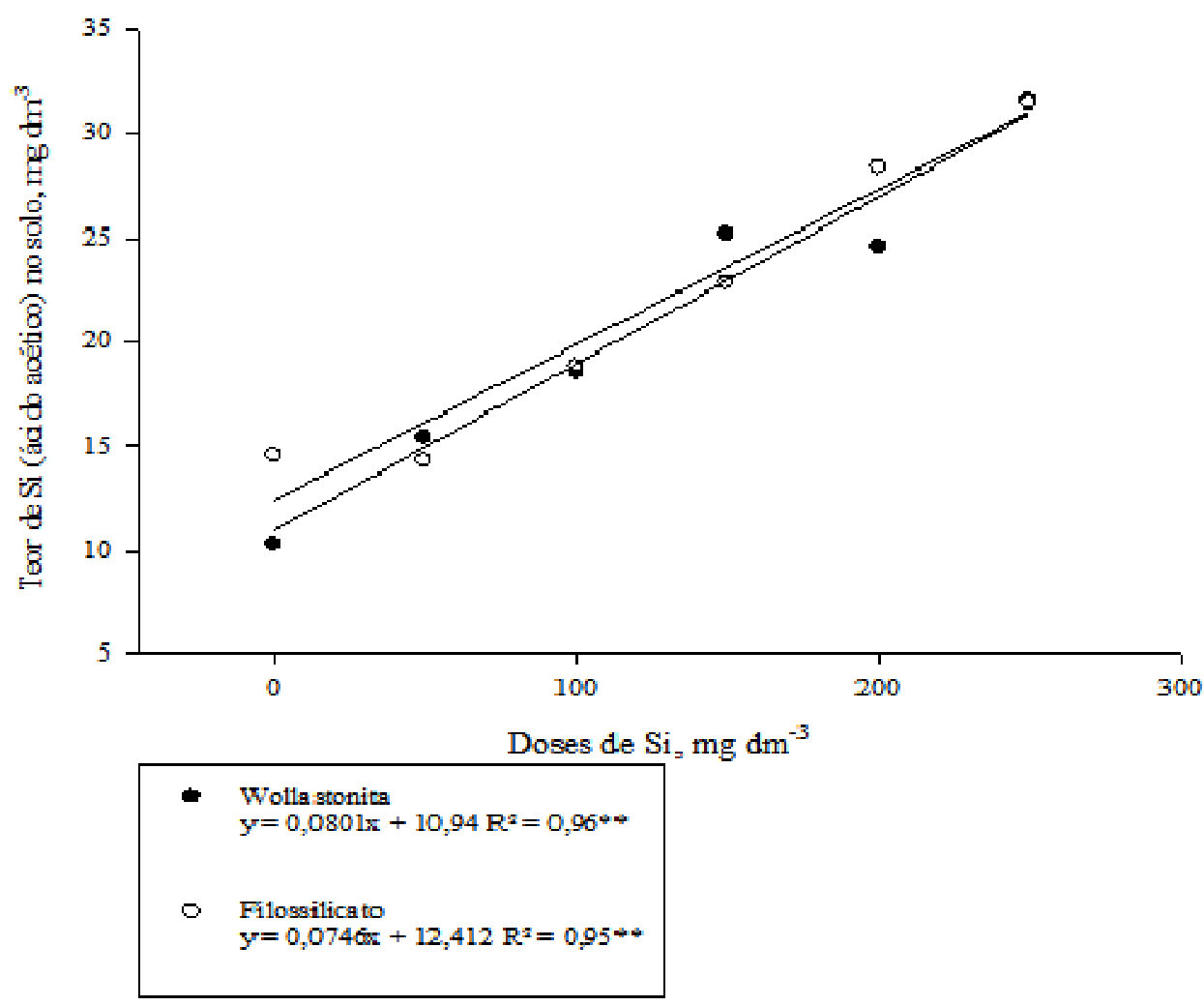

Figura 12 - Teor de silício (Si) no solo extraído por ácido acético, em função da aplicação de fontes e doses de $\mathrm{Si}$.

De acordo com o teste de médias (Tabela 22), observa-se que as duas fontes foram eficazes em liberar o Si no solo e que ambas forneceram este elemento para o solo de forma similar, havendo diferença significativa apenas nas doses de 150 a $200 \mathrm{mg} \mathrm{dm}^{-3}$.

Tabela 22 - Teor de silício (Si) no solo pelo extrator ácido acético em função de doses e fontes de Si, wollastonita e filossilicato.

\begin{tabular}{ccccccc}
\hline Fontes de Si & \multicolumn{5}{c}{ Doses de Si $\left(\mathrm{mg} \mathrm{dm}^{-3}\right)$} \\
& 0 & 50 & 100 & 150 & 200 & 250 \\
\hline Wollastonita & $10,34 \mathrm{~dB}$ & $15,44 \mathrm{cA}$ & $18,60 \mathrm{cA}$ & $25,18 \mathrm{bA}$ & $24,59 \mathrm{bB}$ & $31,58 \mathrm{aA}$ \\
Filossilicato & $14,57 \mathrm{dA}$ & $14,31 \mathrm{dA}$ & $18,87 \mathrm{cA}$ & $22,83 \mathrm{bB}$ & $28,38 \mathrm{aA}$ & $31,44 \mathrm{aA}$ \\
\hline $\mathrm{CV}(\%)$ & 6,35 & & &
\end{tabular}

Letras minúsculas iguais na linha e maiúsculas na coluna não diferem entre si pelo teste de Tukey a 5\%

Observa-se que os valores encontrados com o extrator ácido acético foram superiores aos detectados pelo cloreto de cálcio (Tabelas 21 e 22) tanto neste experimento, quanto nos 
dois anteriores. Este comportamento entre os dois extratores já é observado na literatura e reportado por diversos autores (CAMARGO et al., 2007; RAMOS, KORNDÖRFER; NOLLA, 2008; GUTIERREZ; INOCENCIO; NOVELINO, 2011; ARAUJO; NASCIMENTO; CUNHA, 2011).

Apesar de o ácido acético extrair maiores quantidades de Si em relação ao cloreto de cálcio independentemente da fonte utilizada, o comportamento da liberação deste elemento no solo ocorreu de forma similar para cada dose em função do tempo. Todas as doses de wollastonita e doses entre 100 e $250 \mathrm{mg} \mathrm{dm}^{-3}$ do filossilicato, se ajustaram em regressões cubicas, com liberação máxima próximo de 60 dias (Figuras 13 e 14), no mesmo período que ocorreu para o cloreto de cálcio (Figuras 10 e 11) e corroborando com o período de maior liberação do Si no solo, encontrado por Gomes et al. (2011).

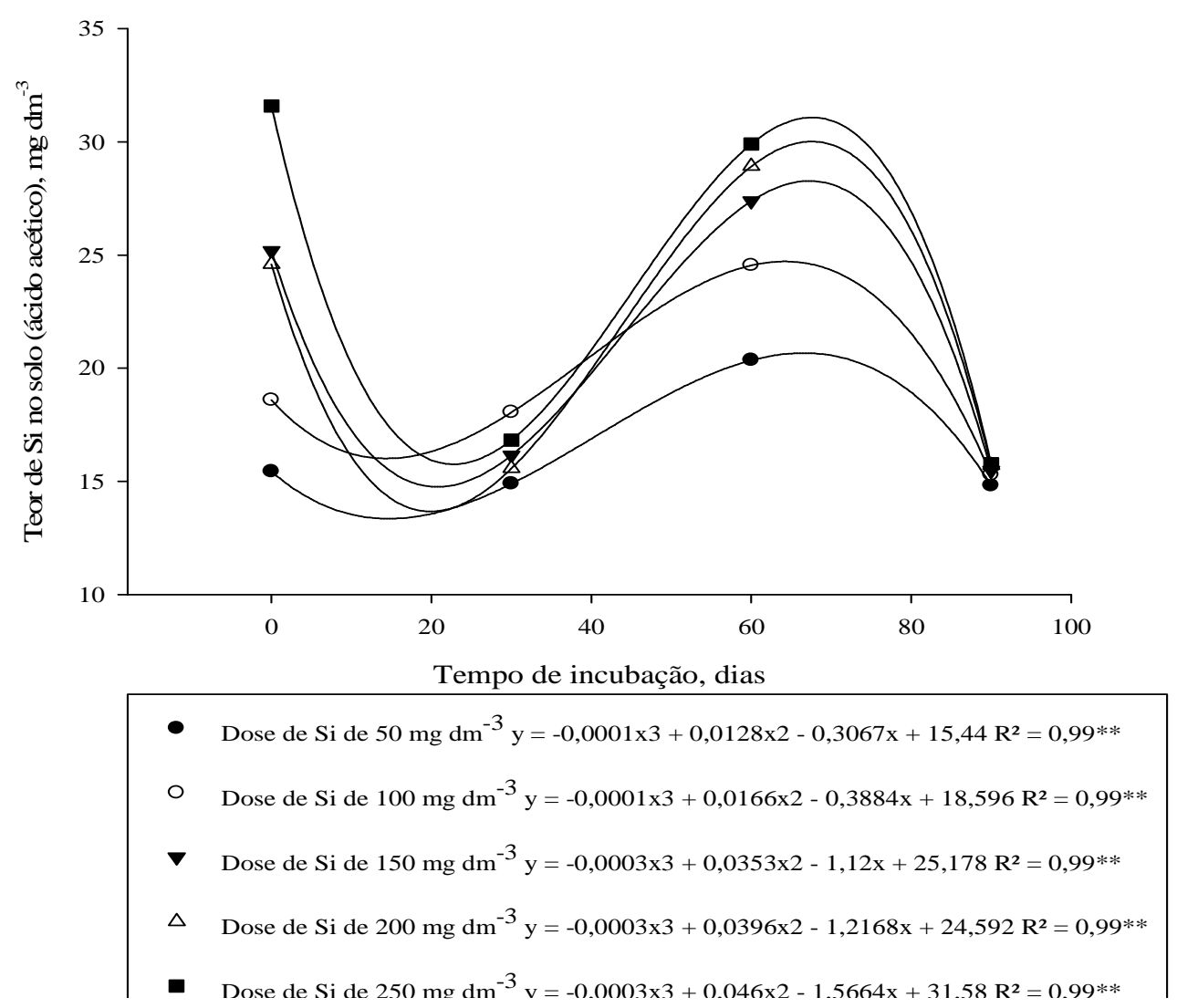

Figura 13 - Teor de silício ( $\mathrm{Si})$ no solo $\left(\mathrm{mg} \mathrm{dm}^{-3}\right)$ extraído por ácido acético pela aplicação de $50,100,150,200$ e $250 \mathrm{mg} \mathrm{dm}^{-3}$ de Si via wollastonita em função dos dias de incubação. 


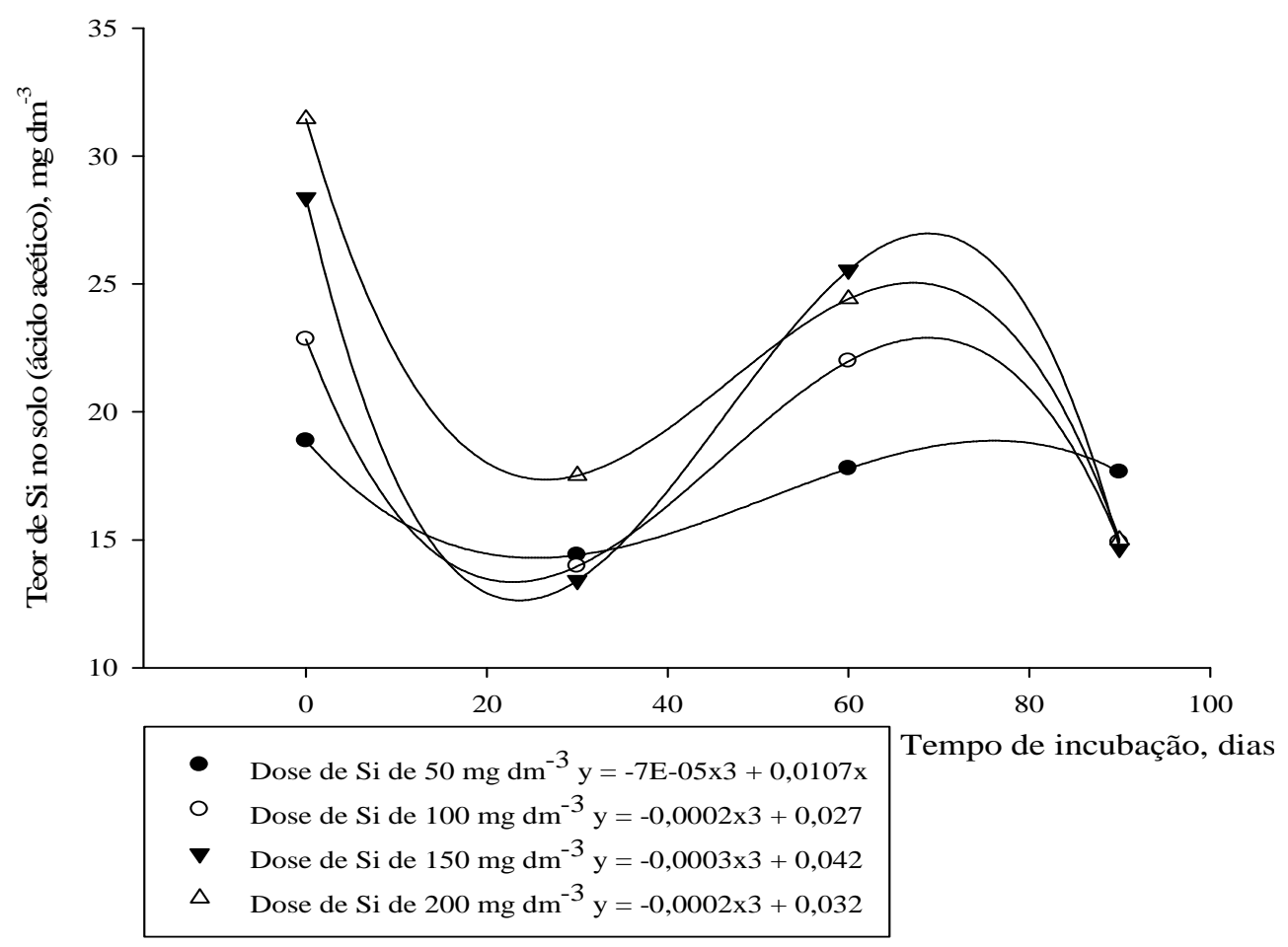

Figura 14 -Teor de silício ( $\mathrm{Si}$ ) no solo $\left(\mathrm{mg} \mathrm{dm}^{-3}\right)$ extraído por ácido acético pela aplicação de 50, 100, 150 e $200 \mathrm{mg} \mathrm{dm}^{-3}$ de Si via filossilicato em função dos dias de incubação.

O teor de P no solo se ajustou em uma regressão linear, em função da aplicação de doses de $\mathrm{Si}$, quando utilizada a fonte de filossilicato. Enquanto que, quando avaliado a partir da aplicação da fonte padrão de Si (wollastonita), não se ajustou em nenhuma curva de regressão (Figura 15). Diferentemente do que ocorreu no experimento 1, em que o filossilicato não se ajustou na curva de regressão, em virtude do incremento no acúmulo de P na MSPA da planta (Figura 2) que fez com que não fossem detectadas alterações significativas do nutriente no solo (Figura 3). Porém, no presente estudo sem a absorção por parte das plantas, o filossilicato promoveu alteração no teor de $\mathrm{P}$ no solo. 


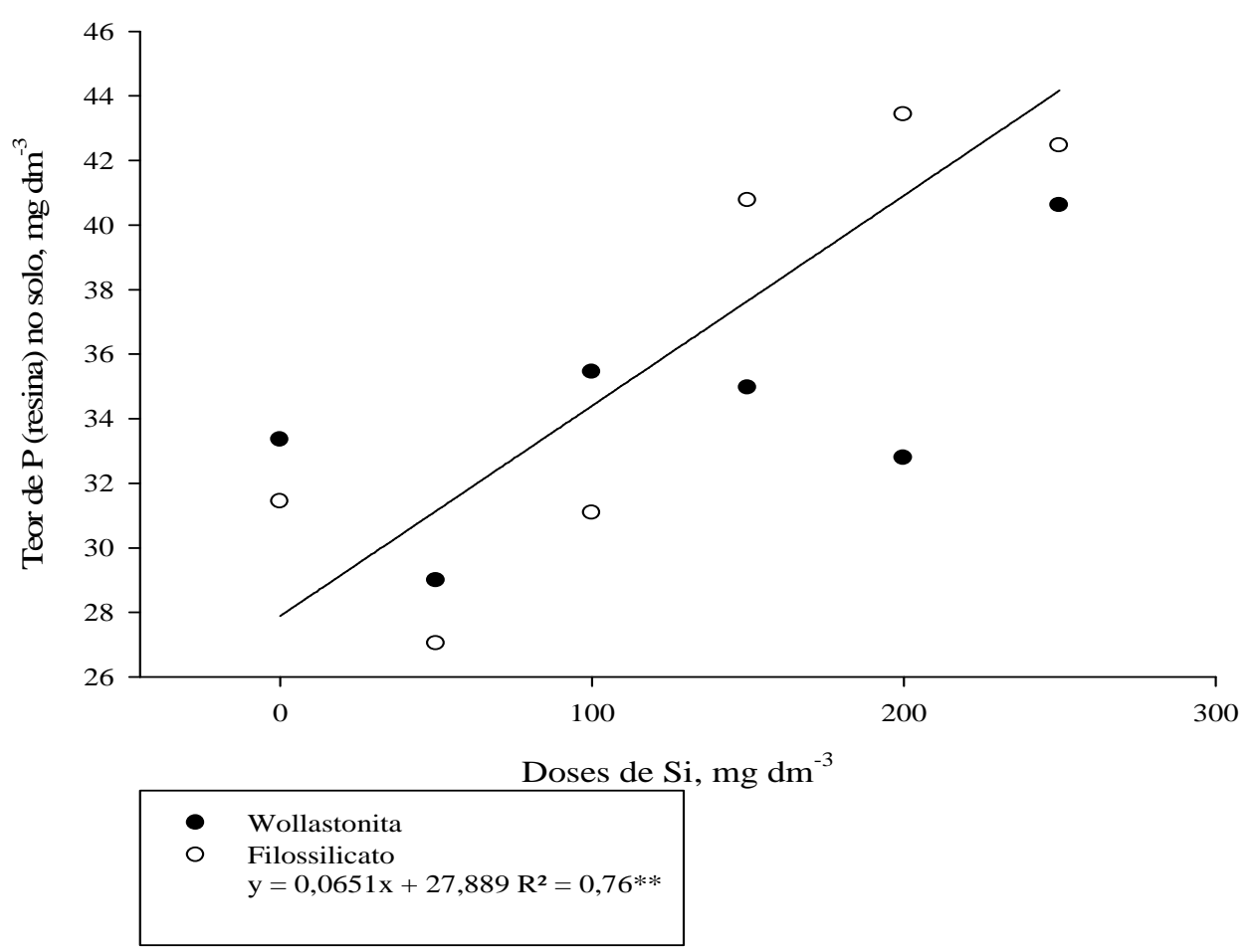

Figura 15 - Teor de fósforo (P) no solo $\left(\mathrm{mg} \mathrm{dm}^{-3}\right)$ pela aplicação fontes wollastonita e fillossilicato nas doses de Si 0, 50, 150, 200 e $250 \mathrm{mg} \mathrm{dm}^{-3}$ incubadas no solo.

Analisando os dados das curvas do teor de $\mathrm{P}$ no solo para cada uma das doses estudadas, os dados obtiveram comportamento similar se observado o tempo necessário para obter os maiores teores deste nutriente no solo, que ocorreram aproximadamente entre 60 a 70 dias de incubação com a wollastonita (Figura 16) e com o filossilicato (Figura 17). 


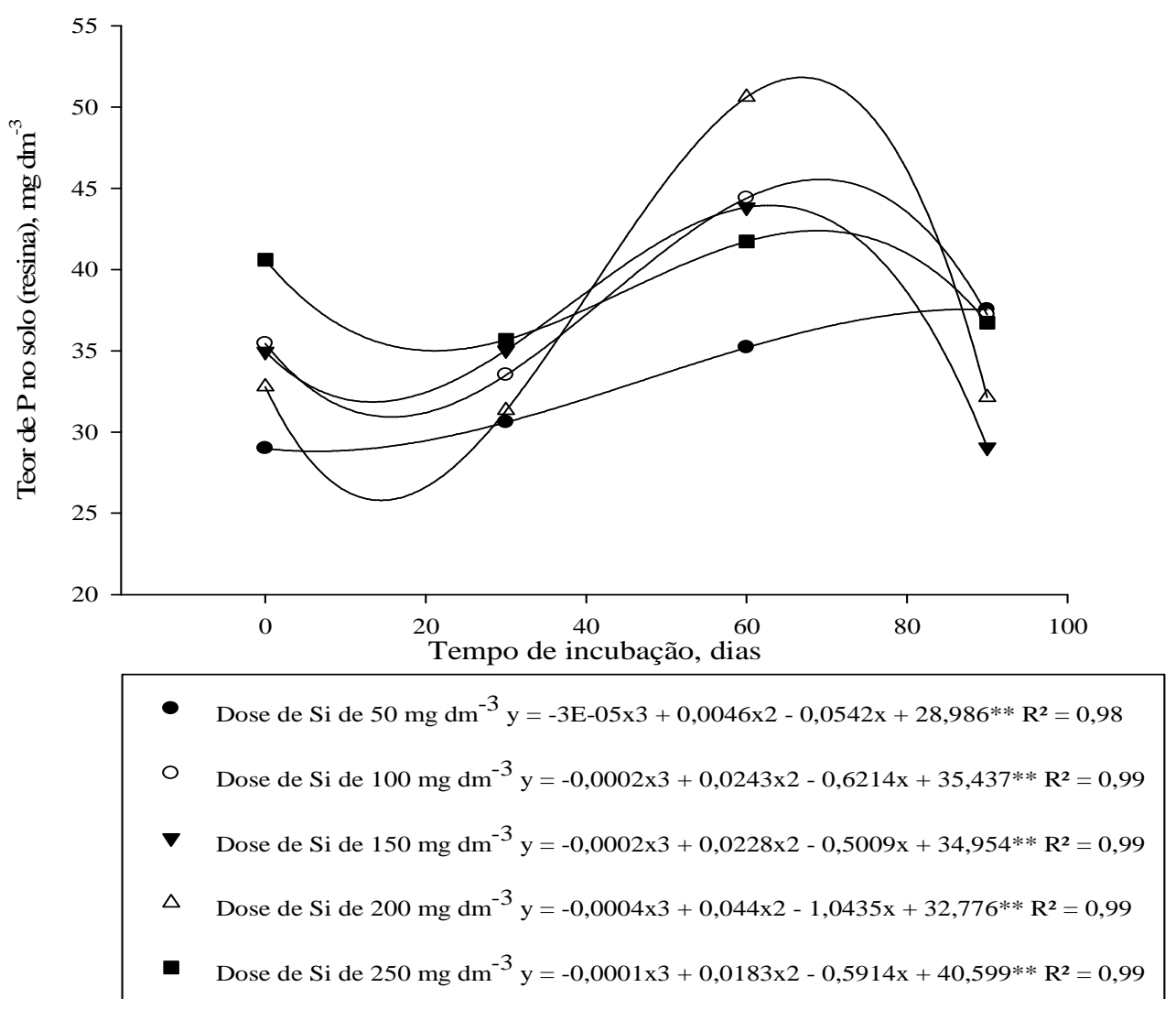

Figura 16 - Teor de fósforo $(\mathrm{P})$ no solo $\left(\mathrm{mg} \mathrm{dm}^{-3}\right)$ pela aplicação de 50; 100; 150 e $200 \mathrm{mg}$ $\mathrm{dm}^{-3}$ de Si via wollastonita em função dos dias de incubação.

Ao se analisar os dados das curvas para cada uma das doses estudadas em função do tempo, para a fonte proveniente de filossilicato, verificou-se as doses se ajustaram em regressões quadráticas (dose 50, 100 e $150 \mathrm{mg} \mathrm{dm}^{-3}$ ) e cúbicas (doses 200 e $250 \mathrm{mg} \mathrm{dm}^{-3}$ ). Entretanto, apesar do comportamento diferente das menores doses em relação às maiores, observa-se que os maiores teores de $\mathrm{P}$ foram obtidos no tempo de, aproximadamente, 60 a 70 dias de incubação (Figura 17). 


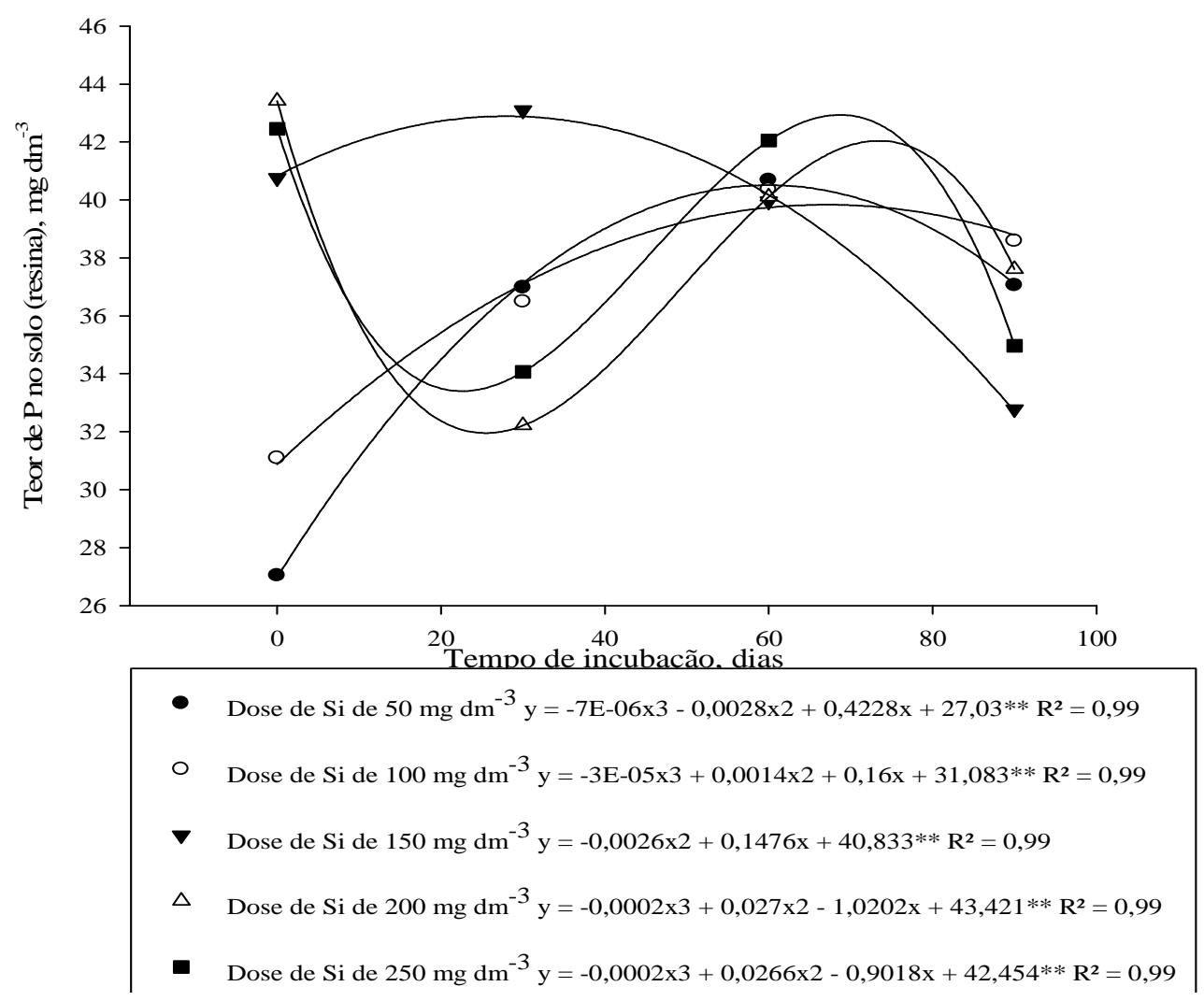

Figura 17 - Teor de fósforo (P) no solo $\left(\mathrm{mg} \mathrm{dm}^{-3}\right)$ pela aplicação de 50; 100; 150 e $200 \mathrm{mg}$ $\mathrm{dm}^{-3}$ de Si via filossilicato em função dos dias de incubação.

Apesar de haver ajuste de regressão para a fonte wollastonita, estas alterações não foram significativas. Mesmo o maior teor de $\mathrm{P}\left(40,60 \mathrm{mg} \mathrm{dm}^{-3}\right)$ no solo obtido por esta fonte, este valor não diferiu em relação ao tratamento controle, que obteve $33,34 \mathrm{mg} \mathrm{dm}^{-3}$. Enquanto para a fonte filossilicato, a partir da dose de $150 \mathrm{mg} \mathrm{dm}^{-3}$ de Si aplicado, obteve-se um teor máximo de 43,42 $\mathrm{mg} \mathrm{dm}^{-3}$, diferindo estatisticamente do teor de fósforo no solo em relação ao tratamento controle $\left(31,43 \mathrm{mg} \mathrm{dm}^{-3}\right)$ (Tabela 23).

Tabela 23 - Teor de fósforo (P) no solo $\left(\mathrm{mg} \mathrm{dm}^{-3}\right)$ em função das doses das fontes de silício (Si), wollastonita e filossicato, no tempo 0 de incubação.

Fontes de $\mathrm{Si}$

Doses de $\mathrm{Si}\left(\mathrm{mg} \mathrm{dm}^{-3}\right)$

$\begin{array}{lllll}0 & 50 & 100 & 150 & 200\end{array}$

Teor de P no solo $\left(\mathrm{mg} \mathrm{dm}^{-3}\right)$

Wollastonita $\quad 33,34 \mathrm{abA} \quad 28,99 \mathrm{bA} \quad 35,44 \mathrm{abA} \quad 34,95 \mathrm{abB} \quad 32,78 \mathrm{bB} \quad 40,60 \mathrm{aA}$

Filossilicato $\quad 31,43 \mathrm{bA} \quad 27,03 \mathrm{bA} \quad 31,08 \mathrm{bA} \quad 40,76 \mathrm{aA} \quad 43,42 \mathrm{aA} \quad 42,45 \mathrm{aA}$

CV $(\%) \quad 9,07$

Letras minúsculas iguais na linha e maiúsculas na coluna não diferem entre si pelo teste de Tukey a 5\% 


\section{CONCLUSÕES}

- As fontes de Si apresentaram comportamento diferente, sendo que o filossilicato promoveu ganhos na produção de MSPA e do P acumulado na parte aérea em relação à fonte padrão de $\mathrm{Si}$, wollastonita;

- O Si proveniente do filossilicato interagiu com o P do solo, deixando-o mais disponível para ser absorvido pelas plantas;

- A wollastonita liberou o Si no solo de forma mais intensa necessitando de doses menores do que o filossilicato;

- A liberação máxima do Si no solo ocorreu aproximadamente dois meses após a aplicação, independente da fonte utilizada;

- O teor de P no solo foi influenciado pelas doses de $\mathrm{Si}$, apresentando teores máximos no solo, no tempo similarmente ao obtido para o $\mathrm{Si}$, para ambas as fontes;

- O acido acético extraiu maiores quantidades de Si do solo em relação ao cloreto de cálcio, porém os dados obtidos com o segundo extrator se correlacionaram com o Si acumulado na planta;

- A forma de aplicação do Si (sulco ou área total) não influenciou nenhuma variável estudada; 


\section{REFERÊNCIAS}

ALCARDE, J.C. Corretivos da acidez dos solos: características e interpretações técnicas. São Paulo: Associação Nacional para Difusão de Adubos e Corretivos, 2005. p. 1-24. (Boletim Técnico, 6).

ARTIGIANI, A. C. C. A.; CRUSCIOL, C. A. C.; NASCENTE, A. S.; ARF, O.; ALVAREZ, R. C. F. Adubação silicatada no sulco e nitrogenada em cobertura no arroz de sequeiro e irrigado por aspersão. Bioscience Journal, Uberlândia, v.30, n3, 2014.

ASSOCIAÇÃO NACIONAL PARA DIFUSÃO DE ADUBOS. Os adubos e a eficiência das adubações. Disponível em: <http://www.anda.org.br/multimidia/boletim_03.pdf>. Acesso em: 25 jun. 2014.

ÁVILA, F.W.; BALIZA, D.P.; FAQUIN, V.; ARAÚJO, J.L.; RAMOS, S.J. Interação entre silício e nitrogênio em arroz cultivado sob solução nutritiva. Revista Ciência Agronômica, Fortaleza, v. 41, n. 2, p. 184-190, 2010.

BAHL, G.S.; PASRICHA, N.S. Effciency of P utilization by pigeonpea and wheat grown in a rotation. Nutrient Cycling in Agroecosystems, Dordrecht, v. 51, n. 3, p. 225-229, 1998.

BALIGAR, V.C.; BENNETT, O.L. NPK-fertilizer efficiency: a situation analysis for the tropics. Fertilizer Research, Dordrecht, v. 10, p. 147-164, 1986.

BALDEÓN, J. R. M. Efeito da ação alcalinizante e da competição entre silicato e fosfato na eficiência do termofosfato magnesiano em solos ácidos. Piracicaba: Esalq, 1995. 88 p.

BARBOSA FILHO, M.P.; SNYDER, G.H.; FAGERIA, N.K.; DATNOFF, L.E.; SILVA, O.F. Silicato de cálcio como fonte de silício para o arroz de sequeiro. Revista Brasileira de Ciência do Solo, Viçosa, v. 25, n. 2, p. 325-330, 2001.

BARROW, N.J. Reaction of anions and cations with variable-charge soils. Advances in Agronomy, New York, v. 38, p. 183-230, 1985.

BRAGA, A.M.C. Eficiência de fontes e doses de fertilizantes contendo silício na adubação do arroz inundado e do sorgo. 2004. 123f. Dissertação de Mestrado em Solos e Nutrição de Plantas) - Instituto de Ciências Agrárias, Universidade Federal de Uberlândia, Uberlândia, 2004

BINGHAM, F.T. Phosphorus. In: CHAPMAN, H.D. (Ed.). Diagnostic criteria for plants and soils. Abilene: Homer D. Chapman, 1966. p. 324-361.

BRASIL. Ministério da Agropecuária e Abastecimento. Disponível em: <http://www.agricultura.gov.br/vegetal/culturas/arroz>. Acesso em: 30 jun. 2014.

CAMARGO, A.O.; MONIZ, A.C.; JORGE, J.A.; VALADARES, J.M. Métodos de análise química, mineralógica e física de solos. Campinas: Instituto Agronômico, 1986. 94 p. (IAC. Boletim Técnico, 106). 
CAMARGO, M. S. de; BARBOSA, D. S.; RESENDE, R. H.; RAMOS, L. A; VIDAL, A. A.; KORNDÖRFER, G. H.; PEREIRA, H. S.; CORREAA, G. F. Disponibilidade de silício em solos: efeito do $\mathrm{pH}$, Si e extratores. In: CONGRESSO BRASILEIRO DE CIÊNCIA DO SOLO, 29. 2003. Anais. Ribeirão Preto, Unesp, 2003.

CAMARGO, M. S. et al. Soil reaction and absorption of silicon by rice. Scientia Agricola, Piracicaba, v. 64, n. 2, p. 176-180, 2007.

CARNEIRO, C. E. A. et al. Calcário, potássio, fosfato e silício na produtividade do solo. Acta Scientiarum Agronomy, Maringá, v. 28, n. 4, p. 465-470, 2006.

CARVALHO, R.; FURTINI NETO, A.E.; CURI, N.; FERNANDES, L.A.; OLIVEIRA Jr, A.C. Dessorção de fósforo por silício em solos cultivados com eucalipto. Revista Brasileira de Ciências do Solo, Viçosa, v. 24, n. 1, p. 69-74, 2000.

CARVALHO, M.A.C.; ARF, O.; SÁ, M.E.; BUZETTI, S.; SANTOS, N.C.B. \& BASSAN, D.A.Z. Produtividade e qualidade de sementes de feijoeiro (Phaseolus vulgaris L.) sob influência de parcelamentos e fontes de nitrogênio. R. Bras. Ci. Solo, 25:617-624, 2001.

CASAGRANDE, J.C.; ALLEONI, L. R. F.; CAMARGO, O. A.; BORGES, M. Adsorção de fosfato e sulfato em solos com cargas elétricas variáveis. Revista Brasileira de Ciência do Solo, Viçosa, v. 27, n. 1, p. 51-59, 2003.

CHIEN, S.H.; MENON, R.G.; BILLINGHAM, K.S. Phosphorus availability from phosphate rock as enhanced by water-soluble phosphorus. Soil Science Society of America Journal, Madison, v. 60, p. 1173-1177, 1996.

COMPANIA NACIONAL DE ABASTECIMENTO. $3^{\circ}$ Levantamento Grãos: safra 2013/14. Disponível em: <http://www.conab.gov.br/OlalaCMS/uploads/arquivos/14_01_10_10_12_36_boletim_portug ues_dezembro_2013.pdf>. Acesso em: 30 jun. 2014.

DATNOFF, L.E.; RODRIGUES, F.A.; SEEBOLD, K.W. Silicon and plant disease. In: DATNOFF, L.E.; ELMER, W.H.; HUBER, D.M. (Org.). Mineral nutrition and plant disease. St. Paul: American Phytopathological Society, 2007. p. 233-246.

ELLIOTT, C.L.; SNYDER, G.H. Autoclave-induced digestion for the colorimetric determination of silicon in rice straw. Journal of Agricultural and Food Chemistry, Washington, v. 39, p. 1118-1119, 1991.

EMBRAPA. Centro Nacional de Pesquisa de Solos. Sistema brasileiro de classificação de solos. 2. ed. Rio de Janeiro, 2006. 306 p.

EPSTEIN, E.; BLOOM, A.J. Nutrição mineral de plantas: princípios e perspectivas. 2. ed. Londrina: Planta, 2006. 403 p.

FAGERIA, N.K,; BALIGAR, V.C.; JONES, C.A. Growth and mineral nutrition of field crops. Boca Raton: CRC Press, 2011. 640 p. 
FAO. Situación alimentaria mundial. Disponível em: <https://www.fao.org.br>. Acesso em: 03 mar. 2010.

FAQUIN, V.; MALAVOLTA, E.; MURAOKA, T. Cinética de absorção de fósforo em soja sob influência de micorriza vesículo-arbuscular. Revista Brasileira de Ciência do Solo, Campinas, v. 14, p. 41-48, 1990.

FARDEU, J.C.; GUIRAUD, G.; MAROL, C. The role of isotopic techniques on the evaluation of the agronomic effectiveness of P fertilizers. Fertilizer Research, Dordrecht, v. 45, p. 101-109, 1996.

FERNANDES, C.; MURAOKA, T. Absorção de fósforo por híbridos de milho cultivados em solo de cerrado. Scientia Agricola, Piracicaba, v. 59, n. 4, p. 781-787, 2002.

FERNÁNDEZ, R.I.E.J.; NOVAIS, R.F.; NUNES, F.N.; KER, J.C. Reversibilidade do fósforo não lábil em solos submetidos à redução microbiana e química. I. Alterações químicas e mineralógicas. Revista Brasileira de Ciência do Solo, Campinas, v. 32, p. 2307-2318, 2008a.

Reversibilidade do fósforo não lábil em solos submetidos à redução microbiana e química. II. Extrações sucessivas do fósforo pela resina de troca aniônica. Revista Brasileira de Ciência do Solo, Campinas, v. 32, p. 2319-2330, 2008b.

FOX, R.L.; SILVA, J.A.; PLUCKNETT, D.L.; TERANISHI, D.Y. Soluble and total silicon in sugar cane. Plant and Soil, Dordrecht, v. 30, n. 1, p. 81-92, 1969.

FOY, C.D. Soil chemical factors limiting plant root growth. In: HATFIELD, J.L.; STEWART, B.A. (Ed.). Limitations to plant root growth. New York: Springer, 1992. p. 97149.

FRANZINI, V.I.; MURAOKA, T.; MENDES, F.L. Ratio and rate effects of 32P-triple superphosphate and phosphate rock mixtures on corn growth. Scientia Agricola, Piracicaba, v. 66, p. 71-76, 2009.

GAO, X.; ZOU, C.; WANG, L.; ZHANG, F. Silicon improves water use efficiency in maize plants. Journal of Plant Nutrition, New York, v. 27, n. 8, p. 1457-1470, 2004.

GOUSSAIN M. M., MORAES, J. C., CARVALHO, J. G., NOGUEIRA, N. L., ROSSI, M. L.. Efeito da aplicação de silício em plantas de milho no desenvolvimento biológico da lagarta-do-cartucho Spodoptera frugiperda (J.E.Smith) (Lepidoptera: Noctuidae). Neotropical Entomology, Londrina, v. 31, n. 2, p. 305-310, 2002.

GRANT, C.A.; FLATEN, D.N.; TOMASIEWICZ, D.J.; SHEPPARD, S.C. A importância do fósforo no desenvolvimento inicial da planta. Informações Agronômicas, Piracicaba, n. 95, p. 1-5, 2001.

HAVLIN, J.L.; BEATON, J.D.; TISDALE, S.L.; NELSON, W.L. Soil fertility and fertilizers: an introduction to nutrient management. 7th ed. New Jersey: Pearson, 2005. 515 p. 
HINGSTON, F.J.; POSNER, A.M.; QUIRK, J.P. Anion desorption by goethite and gibbsite. I. The role of the proton in determining the adsorption envelopes. Journal of Soil Science, v.23, p.177-192, 1972

HODSON, M.J.; WHITE, P. J.; MEAD. A.; BROADLEY, M.R.. Phylogenetic variation in the silicon composition of plants. Annals of Botany, Oxford, v. 96, n. 1, p. 1027-1046, 2005.

KORNDÖRFER, G.H.; DATNOFF, L.E.; CORRÊA, G.F. Influence of silicon on grain discoloration and upland rice growth in four Savanna soils of Brazil. Journal of Plant Nutrition, New York, v. 22, n. 1, p. 93-102, 1999.

KORNDÖRFER, G.H.; PEREIRA, H.S.; CAMARGO, M.S. Silicatos de cálcio e magnésio. 2. ed. Uberlândia: Universidade Federal de Uberlândia, 2002. 23 p. (Boletim Técnico, 1).

LEITE, P.C. Interação silício - fósforo em Latossolo Roxo cultivado com sorgo em casa de vegetação. 1997. 87 p. Tese (Doutorado em Solos e Nutrição de Plantas) - Universidade Federal de Viçosa, Viçosa, 1997.

MA, J.F. Role of silicon in enhancing the resistance of plants to biotic and abiotic stresses. Soil Science and Plant Nutrition, Chiyoda-ku, v. 50, p. 11-18, 2004.

MA, J. F.; TAKAHASHI, E. Soil, fertilizer, and plant silicon research in Japan. Amsterdam: Elsevier Science, 2002. 503 p.

MA, J.F.; YAMAJI, N. Silicon uptake and accumulation in higher plants. Trends in Plant Science, Okayama, v. 11, p. 392-397, 2006.

MA, J.F.; MIYAKE, Y.; TAKAHASHI, E. Silicon as a beneficial element for crop plant. In: DATNOFF, L.E.; KORNDÖRFER, G.H.; SNYDER, G. (Ed.). Silicon in agriculture. New York: Elsevier Science. 2001. p. 17-39.

MALAVOLTA, E. Manual de nutrição mineral de plantas. São Paulo: Agronômica Ceres, 2006. $638 \mathrm{p}$.

MOTOMURA, H.; FUJII, T.; SUZUKI, M. Distribution of silicified cells in the leaf blades of pleioblastus chino (Franchet et Savatier) Makino (Bambusoideae). Annals of Botany, Oxford, v. 85, n. 6, p. 751-757, 2001.

MURAOKA, T. Uso de isópoto em fertilidade do solo. In: OLIVEIRA, A.J.; GARRIDO, W.E.; ARAUJO, J.D.; LOURENÇO, S. Metodologia de pesquisa em fertilidade do solo. Brasília: EMBRAPA, SEA, 1991. p. 255-257.

NEPTUNE, A.M.L.; MURAOKA, T.; STEWART, J.W.B. Efficiency of fertilizer phosphorus utilization by common bean (Phaseolus vulgaris L.) cv. Carioca under different methods of aplying phosphatic fertilizer. Turrialba, San José, v. 29, p. 29-34, 1979.

NOVAIS, R.F.; SMITH, T.J. Fósforo em solo e planta em condições tropicais. Viçosa: Universidade Federal de Viçosa, 1999. 399 p. 
NOVAIS, R.F.; SMYTH, T.J.; NUNES, F.N. Fósforo. In: NOVAIS, R.F.; ALVAREZ V., V.H.; BARROS, N.F.; FONTES, R.L.F.; CANTARUTTI, R.B.; NEVES, J.C.L. Fertilidade do solo. Viçosa: Sociedade Brasileira de Ciência do Solo, 2007. p. 276-374.

ORIOLI JÚNIOR, V. ; A.R.F., O. ; BUZETTI, S. ; COSTA, R. S. S. . Modos de aplicação e doses de silício em dois cultivares de trigo cultivados em semeadura direta. Scientia Agraria (UFPR), v. 9, p. 377-383, 2008.

PEREIRA, H. S.; et al. Avaliação de fontes e de extratores de silício no solo. Pesquisa Agropecuária Brasileira, v. 42, n. 02, p. 239-247, fev. 2007.

PRABHU, A.S.; SANTOS, A.B.; DIDONET, A.D. Soluble tissue sugar content and leaf blast severity in response to the application of calcinated serpentinite as a silicon source in irrigated rice. Summa Phytopathology, Botucatu, v. 33, n. 4, p. 402-404, 2007.

QUEIROZ, A.A. Reação de fontes de silício em quatro solos do cerrado. 2003. 39p. Instituto de Ciências Agrárias - Universidade Federal de Uberlândia, Uberlândia, MG, 2003.

RAIJ, B. van; ANDRADE, J.C. de; CANTARELLA, H.; QUAGGIO, J.A. (Ed.). Análise química para avaliação da fertilidade de solos tropicais. Campinas: Instituto Agronômico, 2001. 285 p.

RAVEN, J.A. Cycling silicon: the role of accumulation in plants. New Phytologist, Sheffield, v. 2, n. 158, p. 419- 421, 2003.

REZENDE, D.C.; RODRIGUES, F.A; CARRÉ-MISSIO, S.D.A.; KAWAMURA, I.K.; KORNDÖRFER, G.H. Effect of root and foliar applications of silicon on brown spot development in rice. Australasian Plant Pathology, Adelaide, v. 38, p. 67-73, 2009.

RODRIGUES, F.A.; BENHAMOU, N.; DATNOFF, L.E.; JONES, J.B.; BÉLANGER, R.R. Ultrastructural and cytochemical aspects of silicon-mediated rice blast resistance. Phytopathology, St. Paul, v. 93, p. 535-546, 2003.

SANDIM, A. S. Disponibilidade de fósforo em função da aplicação de calcário e silicatos em solos oxidicos. Dissertação (Mestrado). Universidade Estadual Paulista. Faculdade de Ciências Agronômicas. 99 fl. Botucatu, SP. 2012.

SANGSTER, A.G., HODSON, M.J.; TUBB, H.J. Silicon deposition in higher plants. In: DATNOFF, L.E.; SNYDER, G.H.; KORNDÖRFER, G.H. (Ed.). Silicon in agriculture. Amsterdam: Elsevier Science, 2001. p. 85-113.

SARRUGE, J.R.; HAAG, H.P. Análises químicas em plantas. Piracicaba: ESALQ, Departamento de Química, 1974. 57 p.

SAS INSTITUTE (Cary, Estados Unidos). The SAS-system for Windows release 6.11 (software). Cary, 1996. 1 CD-ROM. SAS INSTITUTE. SAS user's guide: statistics. $4^{\text {th }}$ ed. Cary, 1996.

SAVANT, N.K.; SNYDER, G.D.; DATNOFF, L.E. Silicon in management and sustainable rice production. Advances in Agronomy, London, v. 58, p. 151-199, 1997. 
SCIVITTARO, W.B.; MURAOKA, T.; BOARETTO, A.E.; TRIVELIN, P.C.O. Utilização de nitrogênio de adubos verdes e mineral pelo milho. Revista Brasileira de Ciências do Solo, Viçosa, v. 34, p. 917-926, 2000.

SILVA, L. S.; BOHNEN, H. Rendimento e acúmulo de nutrientes pelo arroz em solução nutritiva com e sem a adição de silício. Revista Brasileira de Ciência do Solo, Viçosa, MG, v. 25, p. 771-777, 2001.

SMYTH, T.J.; SANCHEZ, P.A. Effects of lime, silicate and phosphorus applications to an oxisol on phosphorus sorption and ion retention. Soil Science Society of America Journal, v.44, p.500-504, 1980.

TAMAI, K.; MA, J.F. Characterization of silicon uptake by rice roots. New Phytologist, Lancaster, v. 158, n. 3, p. 431-436, 2003.

TISDALE, S.L.; NELSON, W.L.; BEATON, J.D.; HAVLIN, J.L. Soil fertility and fertilizers. New York: Macmillan, 1993. 634 p.

TOKURA, A. M. et al. Silício e fósforo em diferentes solos cultivados com arroz de sequeiro. Acta Scientiarum: Agronomy, Maringá, v. 29, n. 1, p. 9-16, 2007.

TOKURA, A.M.; FURTINI NETO, A.E.; CARNEIRO, L.F.; CURI, N.; SANTOS, J.Z.L.; ALOVISI, A.A. Dinâmica das formas de fósforo em solos de textura e mineralogia contrastantes cultivados com arroz. Acta Scientiarum, Agronomy, Maringa, v. 33, n. 1, p. 171-179, 2011.

VIDAL, A.A.; PRADO, R.M. Aplicação de escória siderúrgica, calcário e ureia em Latossolo cultivado com arroz. Pesquisa Agropecuaria Tropical, v.41, p.264-272, 2011.

VOSE, P.B. Introduction to nuclear techniques in agronomy plant biology. London: Pergamon Press, 1980. 391 p.

WIESE, H.; NIKOLIC, M.; RÖMHELD V. Silicon in plant nutrition: effects on zinc, manganese and boron leaf concentrations and compartmentation. In: SATTELMACHER, B.; HORST, W.J. (Ed.). The apoplast of higher plants: compartment of storage, transport and reactions. London: Springer, 2007. p. 33-47.

YOSHIDA, S.; OHNISHI, Y.; KITAGISHI, K. Histochemistry of silicon in rice plant. Soil Science and Plant Nutrition, Tokyo, v. 8, p. 107-111, 1962. 